c. 3

US Army Corps

of Engineers

US-CE-C Property of the

Waterways Experiment Station

\title{
Analysis of Freshwater Mussels (Unionidae) at Specific Sites in Pool 5 and Lake Pepin, Upper Mississippi River, 1994
}

by Andrew C. Miller, Barry S. Payne

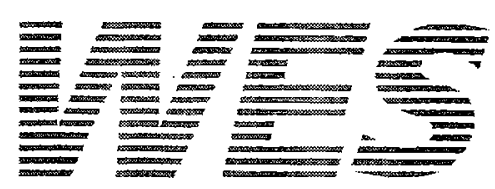

Approved For Public Release; Distribution Is Unlimited

Research Library

US Army Engineer Waterways

Experiment Station

Vicksburg. Mississippi 
The contents of this report are not to be used for advertising, publication, or promotional purposes. Citation of trade names does not constitute an official endorsement or approval of the use of such commercial products.

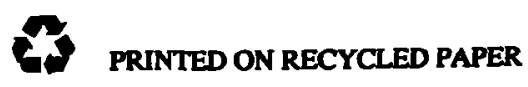




$$
\begin{aligned}
& \text { TA7 } \\
& \text { W34 } \\
& \text { no. EL- } 96-13 \\
& \text { c.3 }
\end{aligned}
$$

Technical Report EL-96-13

September 1996

\section{Analysis of Freshwater Mussels (Unionidae) at Specific Sites in Pool 5 and Lake Pepin, Upper Mississippi River, 1994}

by Andrew C. Miller, Barry S. Payne

U.S. Army Corps of Engineers

Waterways Experiment Station

3909 Halls Ferry Road

Vicksburg, MS 39180-6199

Final report

Approved for public release; distribution is unlimited 


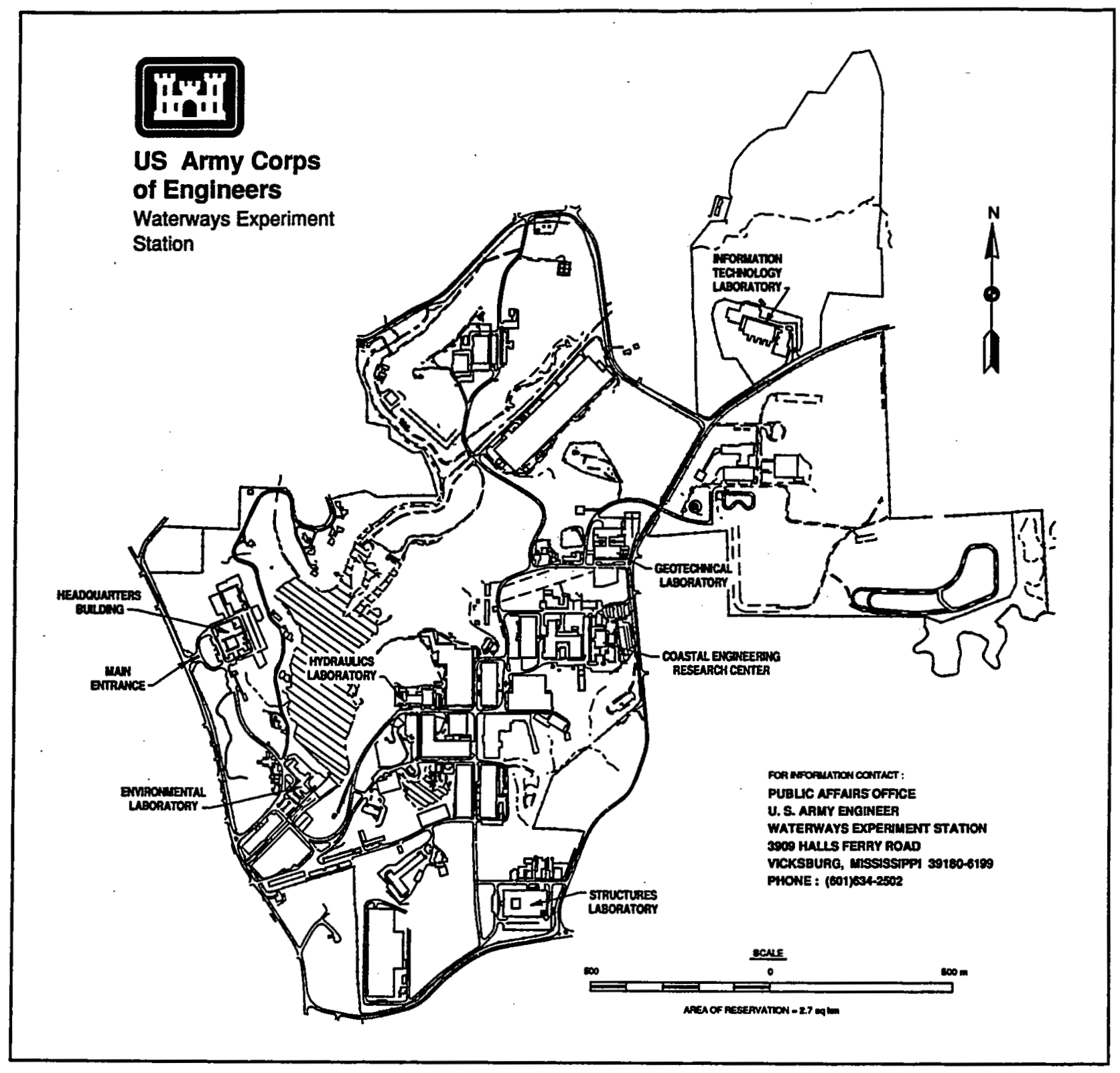

Waterways Experiment Station Cataloging-in-Publication Data

Miller, Andrew C.

Analysis of freshwater mussels (Unionidae) at specific sites in Pool 5 and Lake Pepin, Upper Mississippi River, 1994 / by Andrew C. Miller, Barry S. Payne ; prepared for U.S. Army Engineer Division, North Central.

42 p. : ill. ; $28 \mathrm{~cm}$. -- (Technical report ; EL-96-13)

Includes bibliographic references.

1. Freshwater mussels -- Mississippi River. 2. Unionidae -- Mississippi River. I. Payne, Barry S. II. United States. Army. Corps of Engineers. North Central Division. III. U.S. Army Engineer Waterways Experiment Station. IV. Environmental Laboratory (U.S. Army Engineer Waterways Experiment Station) V. Title. VI. Series: Technical report (U.S. Army Engineer Waterways Experiment Station) ; EL-96-13.

TA7 W34 no.EL-96-13 


\section{Contents}

Preface $\ldots \ldots \ldots \ldots \ldots \ldots \ldots \ldots \ldots \ldots \ldots \ldots$ vi

1-Introduction $\ldots \ldots \ldots \ldots \ldots \ldots \ldots \ldots \ldots \ldots \ldots$

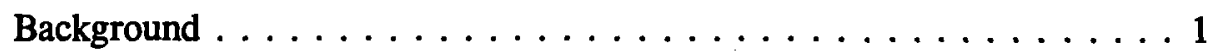

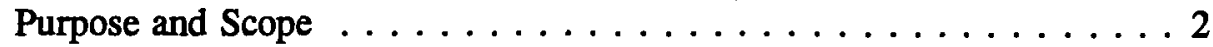

2-Study Areas and Methods $\ldots \ldots \ldots \ldots \ldots \ldots \ldots \ldots$

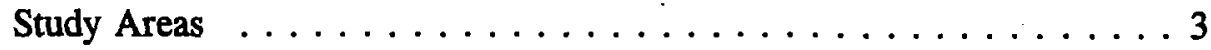

Methods .........................

3-Results $\ldots \ldots \ldots \ldots \ldots \ldots \ldots \ldots \ldots \ldots$

The Mussel Fauna in Pool 5, RM 741.6 . . . . . . . . . 9

The Mussel Fauna in Lake Pepin, RM 776.3 and $764.4 \ldots \ldots . .11$

The Relationship Between Cumulative Number of Species and

Cumulative Number of Individuals $\ldots \ldots \ldots \ldots \ldots \ldots \ldots 12$

Presence of the Zebra Mussel, Dreissena polymorpha . . . . . . 13

Size Demography of Dominant Bivalves at Study Sites in

Lake Pepin and Pool $4 \ldots \ldots \ldots \ldots \ldots \ldots \ldots \ldots$

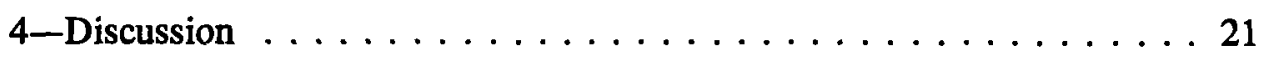

Community and Population Characteristics $\ldots \ldots \ldots \ldots \ldots \ldots 21$

Consideration of Dreissena polymorpha . . . . . . . . . 22

Value of Wingdams for Freshwater Mussels . . . . . . . . 23

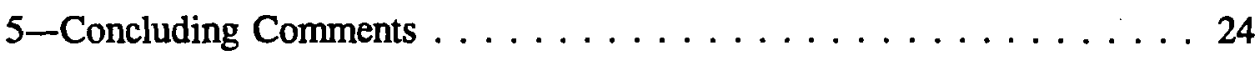

References ..................... 25

Appendix A: Freshwater Bivalves Collected Using Quantitative

Methods at Two Locations in Pool $5,1994 \ldots \ldots \ldots \ldots \ldots \ldots$. . . .

Appendix B: Freshwater Bivalves Collected Using Quantitative

Methods at Two Locations in Lake Pepin, 1994 . . . . . . . . . . . B1

SF 298 


\section{List of Figures}

Figure 1. Sample sites were located in Lake Pepin, downriver of Lake Pepin, and in Pool $5 \ldots \ldots \ldots \ldots$

Figure 2. Sample sites in Pool 5 of the UMR, $1994 \ldots \ldots \ldots$. . . . . . 4

Figure 3. Sample sites located in Lake Pepin of the UMR, 1994 . . . . 5

Figure 4. Sample sites located immediately downriver of Lake Pepin, UMR, $1994 \ldots \ldots \ldots$. . . . . . . . . . . . . . . . 6

Figure 5. Grain size distribution of sediments taken in quantitative samples at three water depths in Lake Pepin . . . . . . . 7

Figure 6. Relationship between the cumulative number of individuals and species collected in Pool 5, RM 741.6, $1994 \ldots \ldots$. . . 14

Figure 7. Relationship between the cumulative number of individuals and species collected $\ldots \ldots \ldots \ldots \ldots \ldots$

Figure 8. Percent unionids infested with zebra mussels six locations in the UMR, including Pool 5 and immediately downriver

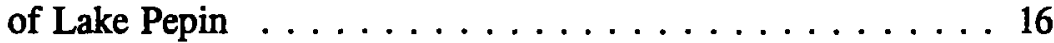

Figure 9. Size demography of dominant bivalves in Pool 5, $1994 \ldots 17$

Figure 10. Size demography of dominant bivalves in Lake Pepin, RM 776.3, $1994 \ldots \ldots \ldots$. . . . . . . . . . . . . . 18

Figure 11. Size demography of dominant bivalves immediately downriver of Lake Pepin, RM 764.4, 1994 . . . . . . . . . . . . 19

Figure 12. Size demography of Dreissena polymorpha on native mussels

\section{List of Tables}

Table 1. Percent Abundance of Freshwater Mussels Collected Using Qualitative Methods in Pool 5 and Lake Pepin, UMR, $1994 \ldots \ldots$. . . . . . . . . . . . . . . . . . 9

Table 2. Percent Occurrence of Freshwater Mussels Collected Using Qualitative Methods in Pool 5 and Lake Pepin, UMR, $1994 \ldots$. . . . . . . . . . . . . . . . . . . . . . . . . 10

Table 3. Percent Abundance of Freshwater Bivalve Species Collected at Two Water Depths Along the Shore of Lake Pepin, Mile 776.3, July 1994 
Table 4. Percent Occurrence of Freshwater Bivalve Species Collected at Two Water Depths Along the Shore of Lake Pepin, Mile 776.3, July $1994 \ldots \ldots$. . . . . . . 12

Table 5. Percent Abundance and Occurrence of Freshwater Bivalves Collected at Sites 9 and 10 Using Quantitative Methods Immediately Downriver of Lake Pepin, River Mile 764.4, July 1994 


\section{Preface}

This report describes results of a survey of freshwater mussel populations (Mollusca: Unionidae) at beds in Pool 5 near Winona, MN, and immediately downriver of Lake Pepin, located in Pool 4 of the upper Mississippi River (UMR). Work was conducted at the request of the U.S. Army Engineer Division, North Central (NCD). The purpose was to collect information on freshwater mussels to evaluate effects of man-made disturbances such as movement of commercial navigation vessels, introduction and spread of the nonindigenous zebra mussel Dreissena polymorpha, or periods of extreme high or low water levels. Funds were also provided by the U.S. Environmental Protection Agency as part of an investigation on the effects of zebra mussels in the UMR.

Divers for this study were Messrs. Larry Neill, Kevin Chalk, Rob James, Jeff Montgomery, and Johnny Buchanan, Tennessee Valley Authority (TVA). Mr. B. Will Green and Mr. Travis Whiting assisted in the field. The diving inspector was Mr. David Rogillio, U.S. Army Engineer Waterways Experiment Station (WES). Ms. Geraldine Wilkerson, Jackson State University, Jackson, MS, prepared all figures except maps; Ms. Erica Hubertz, University of West Florida, Pensacola, and Mr. David Armistead, Millsaps College, Jackson, MS, measured mussels. Foul weather and safety gear was provided by TVA.

During the study, Dr. John Keeley was Chief, Environmental Laboratory, Dr. C. J. Kirby was Chief, Environmental Resources Division, and Dr. Al Cofrancesco was Chief, Aquatic Habitat Group, WES. Authors of this report were Dr. Andrew C. Miller and Dr. Barry S. Payne, WES.

At the time of publication of this report, Director of WES was Dr. Robert W. Whalin. Commander was COL Bruce K. Howard, EN. 
This report should be cited as follows:

Miller, A. C., and Payne, B. S. (1996). "Analysis of Freshwater Mussels (Unionidae) at Specific Sites in Pool 5 and Lake Pepin, Upper Mississippi River, 1994," Technical Report

EL-96-13, U.S. Army Engineer Waterways Experiment Station, Vicksburg, MS.

The contents of this repon are not to be used for advertising, publication, or promotional purposes. Citation of trade names does not constitute an official endorsement or approval of the use of such commercial products. 


\section{Study Areas and Methods}

\section{Study Areas}

The study area in Pool 5 was approximately 11.2 miles downriver of Lock and Dam No. 4, and 3.4 miles upriver of Lock and Dam No. 5 (Figures 1 and 2). An area near three islands on the west central portion of the river near RM 741.5 was searched briefly; however, mussel density was extremely low and no detailed searching was initiated. A total of 40 samples were taken near the channel; 20 on a wingdam and 20 between two wingdams.

Lake Pepin was formed by a constriction caused by deposition of sediments from the Cheppewa River. Near RM 776.3, a total of 20 quantitative samples were collected in $10 \mathrm{ft}$ of water, and 20 samples were taken at each of two sites at a depth of $8 \mathrm{ft}$ (Figure 3). Although Lake Pepin is actually the Mississippi River, there was no obvious flow in this reach and conditions were lacustrine. Ten quantitative samples were taken at Sites 9 and 10 located immediately downriver of the lake and at RM 764.4 (Figure 4).

Sediment grain size distribution from 20 quantitative mussel samples collected at RM 776.3 were analyzed (Figure 5). Fine-grained particles ( $<6.35 \mathrm{~mm}$ ) comprised more than 50 percent of all samples and were most abundant in deep water. Intermediate-sized particles showed no pattern with respect to distance from shore, although larger grain sizes $(>34.0 \mathrm{~mm}$ in diameter) were less abundant in deeper water.

\section{Methods}

\section{Preliminary reconnaissance}

A diver equipped with surface air supply and communication equipment made a preliminary survey of each sample site before detailed studies began. He obtained information on substrate type, water velocity, and presence of mussels. A fathometer was used to measure water depth, and distance to shore was determined with an optical range finder. 


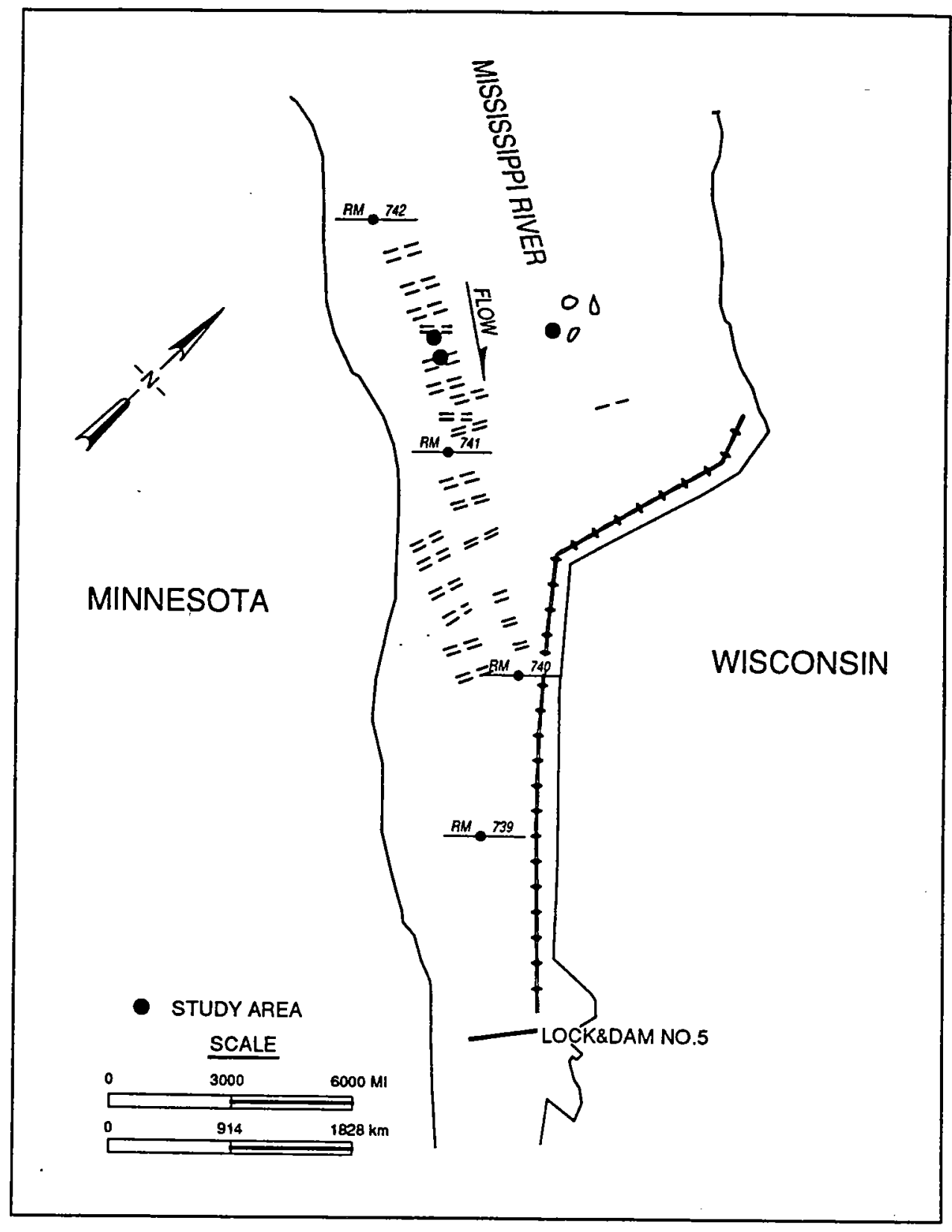

Figure 2. Sample sites in Pool 5 of the UMR, 1994

\section{Qualitative collections}

Qualitative samples were obtained by two divers working simultaneously. The divers had 12 nylon bags between them and were instructed to place approximately 5 mussels in 3 bags and 20 mussels in the remaining 9 bags. Divers attempted to collect only live mussels, although occasionally dead shells were taken that were later discarded. Collection was mainly by feel, since water visibility was poor. Mussels were brought to surface, 


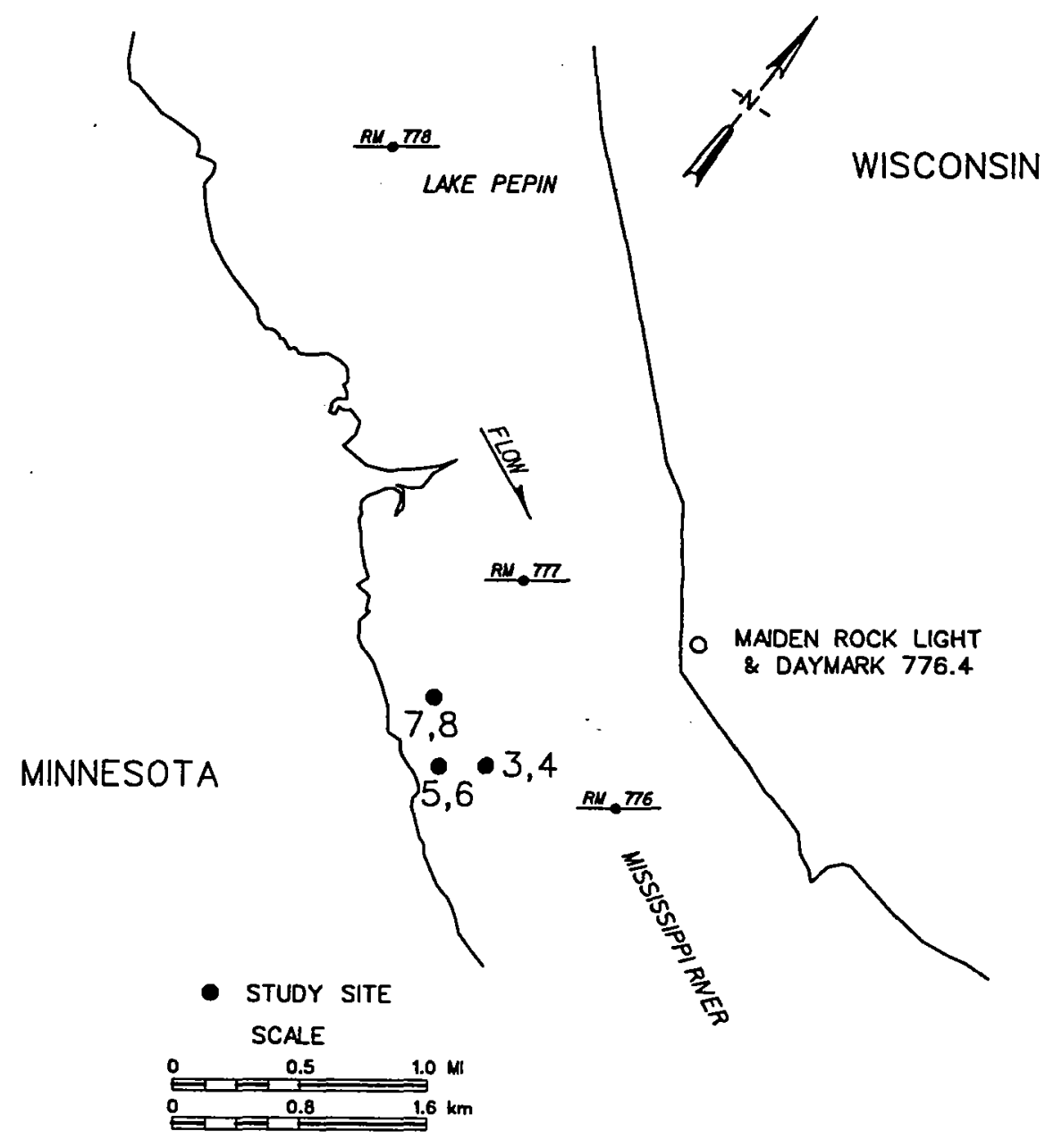

Figure 3. Sample sites located in Lake Pepin of the UMR, 1994

identified, and counted. Selected mussels were shucked and retained for voucher. Unneeded specimens were returned to the river unharmed.

\section{Quantitative sampling}

Ten total substratum samples were obtained at each site chosen for quantitative collecting. Aluminum quadrats $\left(0.25 \mathrm{~m}^{2}\right)$ were placed approximately $1 \mathrm{~m}$ apart and arranged in a $2 \times 5$ matrix. A diver removed all sand, gravel, shells, and live molluscs within the quadrat. It usually took 5 to $10 \mathrm{~min}$ to clear the quadrat to a depth of 10 to $15 \mathrm{~cm}$. All material was sent to the surface in a 20-liter bucket, taken to shore, and sieved through a nested screen series (screen size apertures were $34.0,12.7$, and $6.3 \mathrm{~mm}$ ) and picked for live organisms. All bivalves were identified, and total shell length (SL) was measured to the nearest $0.1 \mathrm{~mm}$. Some bivalves were measured during the day or 


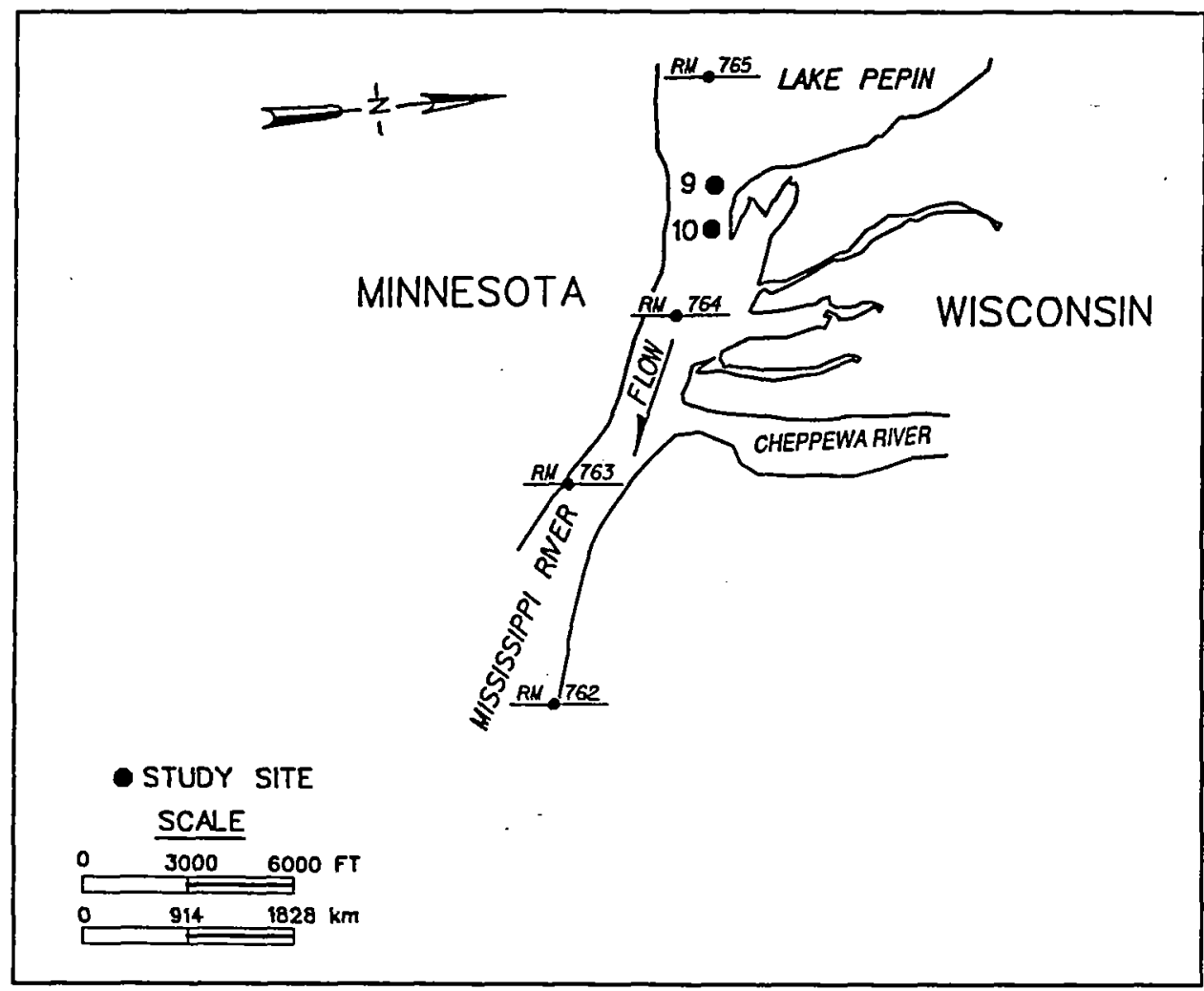

Figure 4. Sample sites located immediately downriver of Lake Pepin, UMR, 1994

in the evening, then returned to the river the next day. Bivalves that could not be processed within 24 hours were preserved in 10 percent buffered formalin and returned to the laboratory for analysis.

All sediments on each screen were weighed after mussels had been removed. The weights of each sediment fraction was used to estimate grain size distribution in the following size categories: greater than $34.0 \mathrm{~mm}$, between 34.0 and $12.7 \mathrm{~mm}$, between 6.3 and $12.7 \mathrm{~mm}$, and less than $6.3 \mathrm{~mm}$. This method had the advantage of quantifying grain sizes of each sample where mussels were collected. Alternatively, grain size analysis is performed on samples taken from the vicinity of quantitative samples.

A suction dredge, powered by an 8-hp engine that was attached to a flexible line, was used to collect mussels at some sites. A single diver removed live specimens, shells, and gravel (less than $7.6 \mathrm{~cm}$, the diameter of the intake) within a $0.25 \mathrm{~m}^{2}$ aluminum quadrat. Specimens larger than the intake diameter were removed by hand and sent to the surface in a mesh bag. On the wingdams it was not practical to use the quadrat, and the diver worked until approximately 10 organisms were collected. This comprised a single sample. This method was faster than the total substratum method, obtained small-sized mussels, but did not provide a quantitative collection of 


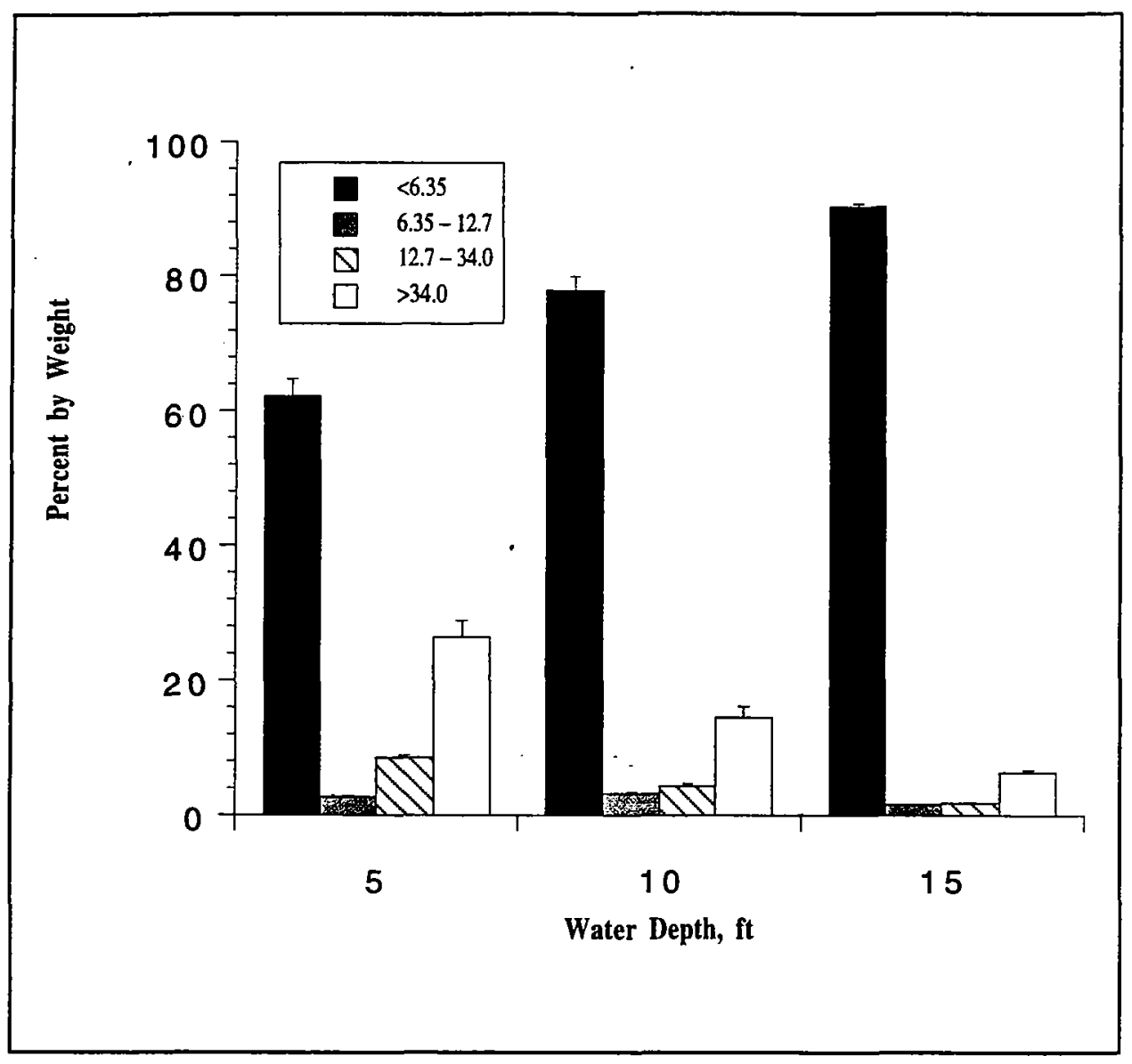

Figure 5. Grain size distribution of sediments taken in quantitative samples at three water depths in Lake Pepin

substratum, since large sediment particles larger than the intake orifice could not be collected.

\section{Data analysis}

Data from qualitative and quantitative collections were recorded on standard data sheets and returned to the laboratory for analysis and plotting. Methods for sampling mussels are based on techniques described by Isom and Gooch (1986); Kovalak, Dennis, and Bates (1986); Miller and Payne (1988); and Miller et al. (1994). Mussel identification was based on taxonomic keys and descriptive information by Murray and Leonard (1962); Parmalee (1967); Starrett (1971); and Burch (1975). Taxonomy is consistent with Williams et al. (1992).

Species diversity was determined with the following formula: 


$$
H^{\prime}=-p_{j} \log p_{j}
$$

where $p_{j}$ is the proportion of the population that is of the $j^{\text {th }}$ species (Shannon and Weaver 1949). All calculations were done with programs written in BASIC or SAS (Statistical Analytical System) on a personal computer. 


\section{Results}

\section{The Mussel Fauna in Pool 5, RM 741.6}

\section{Community characteristics and density}

Based on results of this survey, areas on and between wingdams supported higher mussel densities than did open-river sites to the North and East (Figure 2). Based upon all qualitative sampling at study sites in this pool, 337 individuals and 14 unionid species were collected. The fauna was dominated by Amblema $p$. plicata which comprised slightly more than 50 percent of the community and was found in 100 percent of the samples (Tables 1,2 ). A total of nine species each comprised 1 to 10 percent of the fauna; the remaining four species each comprised less than 1 percent of the fauna.

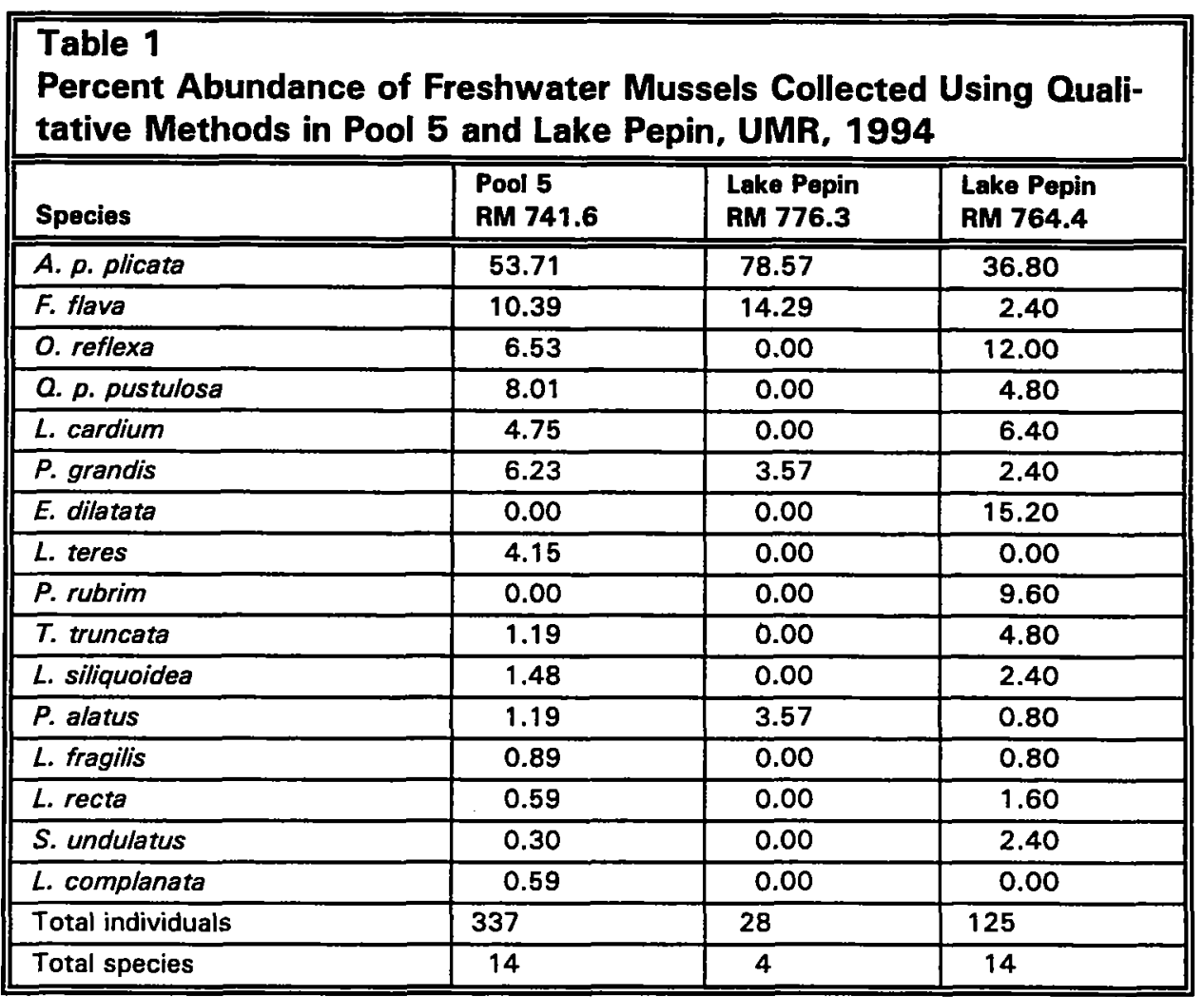




\begin{tabular}{|c|c|c|c|}
\hline \multicolumn{4}{|c|}{$\begin{array}{l}\text { Table } 2 \\
\text { Percent Occurrence of Freshwater Mussels Collected Using Qual } \\
\text { tative Methods in Pool } 5 \text { and Lake Pepin, UMR, } 1994\end{array}$} \\
\hline Species & $\begin{array}{l}\text { Pool 5 } \\
\text { RM 741.6 }\end{array}$ & $\begin{array}{l}\text { Lake Pepin } \\
\text { RM } 776.3\end{array}$ & $\begin{array}{l}\text { Lake Pepin } \\
\text { RM } 764.4\end{array}$ \\
\hline A. p. plicata & 100.00 & 100.00 & 87.50 \\
\hline F. flava & 91.67 & 33.33 & 25.00 \\
\hline O. reflexa & 66.67 & 0.00 & 62.50 \\
\hline L. cardium & 50.00 & 0.00 & 62.50 \\
\hline Q. p. pustulosa & 58.33 & 0.00 & 37.50 \\
\hline L. siliquoidea & 41.67 & 0.00 & 25.00 \\
\hline T. truncata & 16.67 & 0.00 & 62.50 \\
\hline P. grandis & 41.67 & 16.67 & 00.0 \\
\hline E. dilatata & 0.00 & 0.00 & 62.50 \\
\hline P. alatus & 25.00 & 16.67 & 12.50 \\
\hline L. teres & 33.33 & 0.00 & 0.00 \\
\hline L. recta & 16.67 & 0.00 & 25.00 \\
\hline S. undulatus & 8.33 & 0.00 & 37.50 \\
\hline P. rubrim & 0.00 & 0.00 & 50.00 \\
\hline L. complanata & 16.67 & 0.00 & 0.00 \\
\hline L. fragilis & 8.33 & 0.00 & 12.50 \\
\hline Total samples & 12 & 8 & 6 \\
\hline
\end{tabular}

A total of 20 substratum samples were taken with a suction pump at two subsites on a wingdam, and 20 were taken at a site between two wingdams (Appendix A, Tables A1, A2). A total of 223 individuals and 12 species were collected in 20 samples on the wingdam. The fauna was dominated by $A . p$. plicata which comprised 60 percent of the fauna and was collected in 100 percent of the samples. There was evidence of recent recruitment: 8.4 percent of the individuals and 36.4 percent of the species were less than $30 \mathrm{~mm}$ total shell length. Because the diver worked without a quadrat on the wingdams, density estimates could not be made. However, these samples are equivalent to total substratum samples collected by hand in that they provide accurate estimates of recent recruitment.

Total mean density between the wingdams was 10.0 individuals $/ \mathrm{m}^{2}$. A total of eight species were collected and the fauna was dominated by A. p. plicata and Quadrula p. pustulosa. Evidence of recent recruitment was similar to that on the wingdams; overall 12 percent of the individuals and 50 percent of the species were less than $30 \mathrm{~mm}$ total shell length. A total of 8 species were taken between the wingdams, and 12 species were taken on the wingdams. Slightly higher species richness on the wingdams was likely due to the increased number of sites for mussels among the various-sized cobble and gravel as compared with sand and gravel between wingdams. 


\section{The Mussel Fauna in Lake Pepin, RM 776.3 and 764.4}

Qualitative and quantitative samples were obtained along the right descending bank of the lake proper, near RM 776.3 and immediately downriver of the lake at RM 764.4 (Figures 1, 3, 4). Qualitative sampling near RM 776.3 yielded only 28 individuals and 4 species (Table 1 and Appendix B). In the reach immediately downriver of the lake, 125 individuals and 14 species were collected using qualitative methods. Amblema $p$. plicata was less dominant but more dense at RM 764.4 than at RM 776.3. Elliptio dilatata and Q. p. pustulosa, which were not found in Lake Pepin, each comprised 15.2 and 12 percent, respectively, of the fauna immediately downriver of the lake.

Density was dependent on water depth in Lake Pepin (Tables 3, 4). Density in $10 \mathrm{ft}$ of water, 2.4 individuals $/ \mathrm{m}^{2}$, was significantly less than at a depth of $5 \mathrm{ft}, 6.3$ individuals $/ \mathrm{m}^{2}$. Evidence of recent recruitment was good at both water depths ( 22 to 25 percent of the individuals and 50 to 71 percent of the species were less than $30 \mathrm{~mm}$ total shell length).

\begin{tabular}{|c|c|c|c|}
\hline \multicolumn{4}{|c|}{$\begin{array}{l}\text { Table } 3 \\
\text { Percent Abundance of Freshwater Bivalve Species Collected at } \\
\text { Two Water Depths Along the Shore of Lake Pepin, Mile 776.3, } \\
\text { July } 1994 \text { (Figure } 3 \text { ) (Means with different superscripts are sig- } \\
\text { nificantly different based on Duncan's Multiple Range Test } \\
(p<0.05 \text { ) }\end{array}$} \\
\hline \multirow[b]{2}{*}{ Species } & \multicolumn{2}{|c|}{ Water Depth, ft } & \multirow[b]{2}{*}{ Total } \\
\hline & 5 & 10 & \\
\hline A. p. plicata & 38.1 & 66.67 & 42.67 \\
\hline F. flava & 39.68 & 8.33 & 34.67 \\
\hline O. reflexa & 7.94 & 16.67 & 9.33 \\
\hline L. cardium & 3.17 & 8.33 & 4.00 \\
\hline D. polymorpha & 4.76 & 0.00 & 4.00 \\
\hline T. truncata & 3.17 & 0.00 & 2.67 \\
\hline T. donaciformis & 1.59 & 0.00 & 1.33 \\
\hline L. siliquoidea & 1.59 & 0.00 & 1.33 \\
\hline Total individuals & 63 & 12 & 75 \\
\hline Mean density & $6.3^{\mathrm{a}}$ & $2.4^{b}$ & - \\
\hline Standard error & 0.74 & 0.73 & -- \\
\hline Total species & 8 & 4 & 8 \\
\hline Percent individuals $<30 \mathrm{~mm}$ & 21.67 & 25 & 22.22 \\
\hline Percent species $<30 \mathrm{~mm}$ & 71.4 & 50 & 71.42 \\
\hline Menhinik's index & 0.90 & 1.15 & 0.82 \\
\hline Diversity $\left(\mathrm{H}^{\prime}\right)$ & 0.33 & 0.98 & 1.3 \\
\hline Evenness & 0.75 & 0.76 & 0.75 \\
\hline
\end{tabular}




\begin{tabular}{|c|c|c|c|}
\hline \multicolumn{4}{|c|}{$\begin{array}{l}\text { Table } 4 \\
\text { Percent Occurrence of Freshwater Bivalve Species Collected at } \\
\text { Two Water Depths Along the Shore of Lake Pepin, Mile 776.3, } \\
\text { July } 1994\end{array}$} \\
\hline \multirow[b]{2}{*}{ Species } & \multicolumn{2}{|c|}{ Water Depth, ft } & \multirow[b]{2}{*}{ Total } \\
\hline & 5 & 10 & \\
\hline A. p. plicata & 47.50 & 25.0 & 40.00 \\
\hline F. flava & 52.50 & 5.0 & 36.67 \\
\hline O. reflexa & 12.50 & 10.0 & 11.67 \\
\hline L. cardium & 5.00 & 5.0 & 5.00 \\
\hline D. polymorpha & 7.50 & 0.0 & 5.00 \\
\hline T. truncata & 5.00 & 0.0 & 3.33 \\
\hline T. donaciformis & 2.50 & 0.0 & 1.67 \\
\hline L. siliquoidea & 2.50 & 0.0 & 1.67 \\
\hline Total samples & 40 & 20 & 60 \\
\hline
\end{tabular}

Density in the reach immediately downriver of Lake Pepin was 19.6 individuals $/ \mathrm{m}^{2}$, which was substantially greater than in the lake (Table 5). Evidence of recent recruitment was apparent in 19 percent of the individuals and 50 percent of the species; these numbers were similar to those at two water depths in the lake. Dreissena polymorpha was more abundant in this reach immediately downriver of the lake (14.3 percent) than they were in the lake ( 4 percent) or at sites surveyed in Pool 5 (less than 5 percent).

\section{The Relationship Between Cumulative Number of Species and Cumulative Number of Individuals}

The relationship between the cumulative number of species and individuals collected provides a means to quantify the difficulty of collecting uncommon species. Although a greater number of individual mussels were collected on wingdams as compared with the number collected between wingdams, the ability to identify new species based on collecting effort was approximately equal (Figure 6). It is likely that if more individuals had been collected between the wingdams, additional species would have been identified. Although physical habitat conditions were quite different on wingdams as compared with conditions between wingdams, the biotic community was similar at both locations.

Four species were identified in a collection of 12 individuals in 10-ft-deep water in Lake Pepin (Figure 7a). When an additional 60 individuals were collected at $5 \mathrm{ft}$, two more species were identified. Downriver of Lake Pepin, 11 species and approximately 80 individuals were collected (Figure $7 \mathrm{~b}$ ). Overall species richness was greater at this site than in the lake. In addition, the ability of finding new species was greater immediately downriver of the lake than in the lake proper. 


\begin{tabular}{|c|c|c|}
\hline \multicolumn{3}{|c|}{$\begin{array}{l}\text { Table } 5 \\
\text { Percent Abundance and Occurrence of Freshwater Bivalves Col- } \\
\text { lected at Sites } 9 \text { and } 10 \text { Using Quantitative Methods Immediately } \\
\text { Downriver of Lake Pepin, River Mile 764.4, July } 1994 \text { (Figure 4) }\end{array}$} \\
\hline Species & Percent Abundance & Percent Occurrence \\
\hline A. p. plicata & 37.76 & 75.00 \\
\hline E. dilatata & 9.18 & 35.00 \\
\hline F. flava & 1.02 & 5.00 \\
\hline L. cardium & 9.18 & 35.00 \\
\hline L. recta & 2.04 & 10.00 \\
\hline O. reflexa & 5.10 & 20.00 \\
\hline P. rubrim & 5.10 & 25.00 \\
\hline Q. metanevra & 1.02 & 5.00 \\
\hline Q. pustulosa & 3.06 & 15.00 \\
\hline T. truncata & 12.24 & 55.00 \\
\hline D. polymorpha & 14.29 & 40.00 \\
\hline Total individuals & 98 & \\
\hline Mean density & 19.60 & \\
\hline Standard error & 2.69 & \\
\hline Total species & 11 & \\
\hline Total samples & 20 & \\
\hline Percent individuals $<30 \mathrm{~mm}$ & 19.05 & \\
\hline Percent species $<30 \mathrm{~mm}$ & 50.00 & \\
\hline Menhinik's index & 1.09 & \\
\hline Diversity $\left(H^{\prime}\right)$ & 1.77 & \\
\hline Evenness & 0.66 & \\
\hline
\end{tabular}

\section{Presence of the Zebra Mussel, Dreissena polymorpha}

Zebra mussels taken in total substratum samples were either attached to native mussel shells or attached to gravel or dead shells in the substratum. Total density of $D$. polymorpha in Lake Pepin at $5 \mathrm{ft}$ was approximately 0.3 individuals $/ \mathrm{m}^{2}$ and immediately downriver of the lake density was approximately 2.8 individuals $/ \mathrm{m}^{2}$. Dreissena polymorpha comprised approximately 4 percent of the fauna on the wingdams but was not collected between wingdams. Presumably free floating veligers and adults were more likely to be trapped by eddies among the coarse material comprising the wingdams than the natural sand-gravel substratum. Approximately 31 percent of the live unionids collected immediately downriver of Lake Pepin had at least one unionid attached to the shell (Figure 8). Infestation at this location was considerably greater than at any other beds surveyed in the UMR in 1994. 


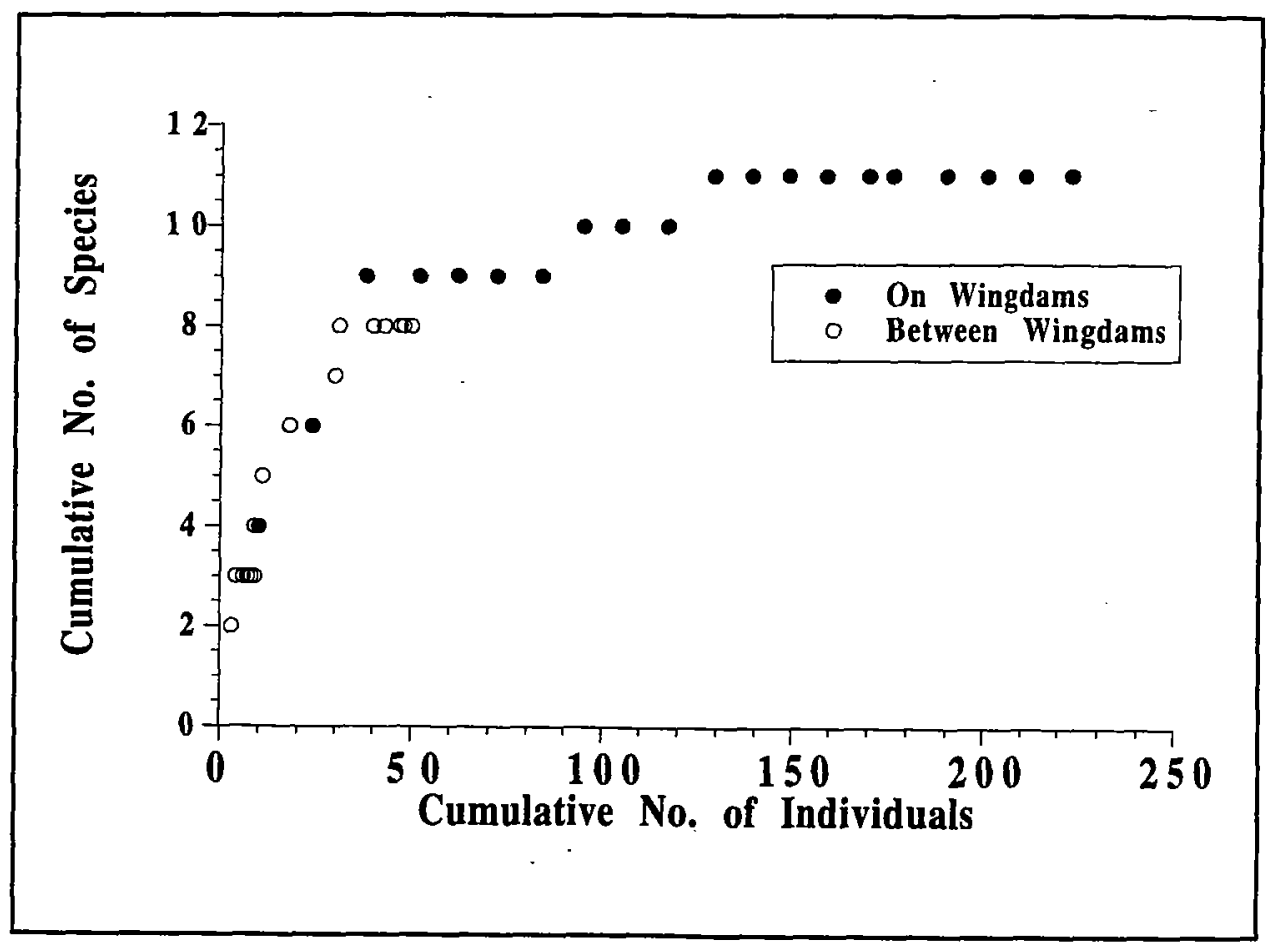

Figure 6. Relationship between the cumulative number of individuals and species collected in Pool 5, RM 741.6, 1994

\section{Size Demography of Dominant Bivalves at Study Sites in Lake Pepin and Pool 4}

a. Amblema p. plicata. The length range of this species was similar at all locations; length ranged from 16 to $90 \mathrm{~mm}$ at $\mathrm{RM} 741.6,18$ to $98 \mathrm{~mm}$ at RM 764.4, and 14 to $100 \mathrm{~mm}$ at RM 776.3 (Figures 9 through 11). Although sample sizes were relatively small at RM 764.4 and 776.3, large $A$. p. plicata appeared to be less abundant relative to small individuals at these two locations than at RM 741.6. Even at RM 741.6, not enough individuals were collected to support detailed demographic analysis. However, it was readily apparent that the $A$. p. plicata population at this location was comprised of multiple year classes, with peaks at $21,45,53,66$, and $79 \mathrm{~mm}$ representing the average length of abundant cohorts. Mussels ranging from 56 to $64 \mathrm{~mm}$ comprised 56 percent of the population at RM 741.6 and probably represented one or two especially abundant-year classes.

b. Fusconaia flava. Enough individuals were collected of this species to support at least general analysis of size demography at RM 776.3 $(n=26)$. Mussels ranged in length from 8 to $66 \mathrm{~mm}$. Two individuals less than $30 \mathrm{~mm}$ long were collected, but this comprised 11 percent 


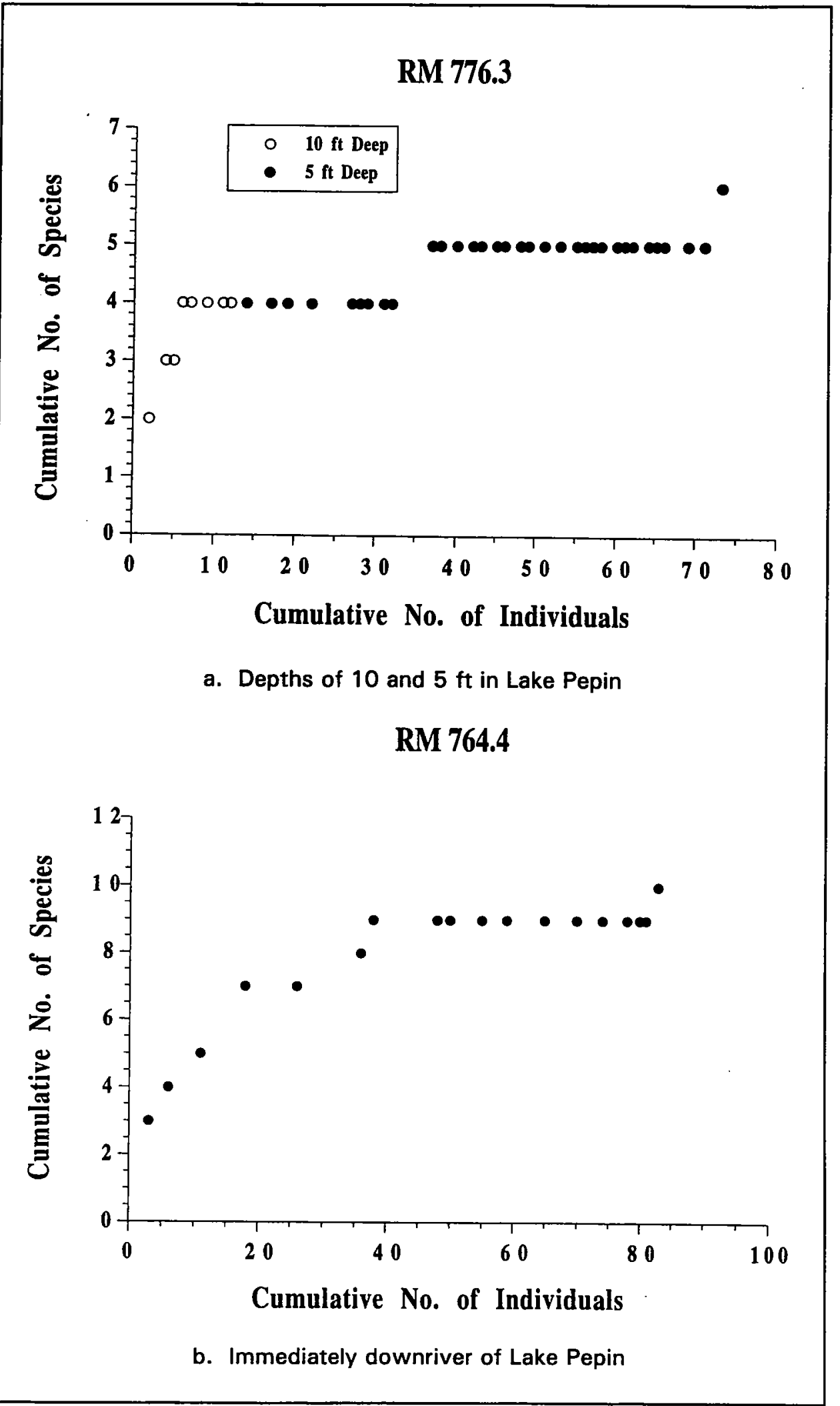

Figure 7. Relationship between the cumulative number of individuals and species collected 


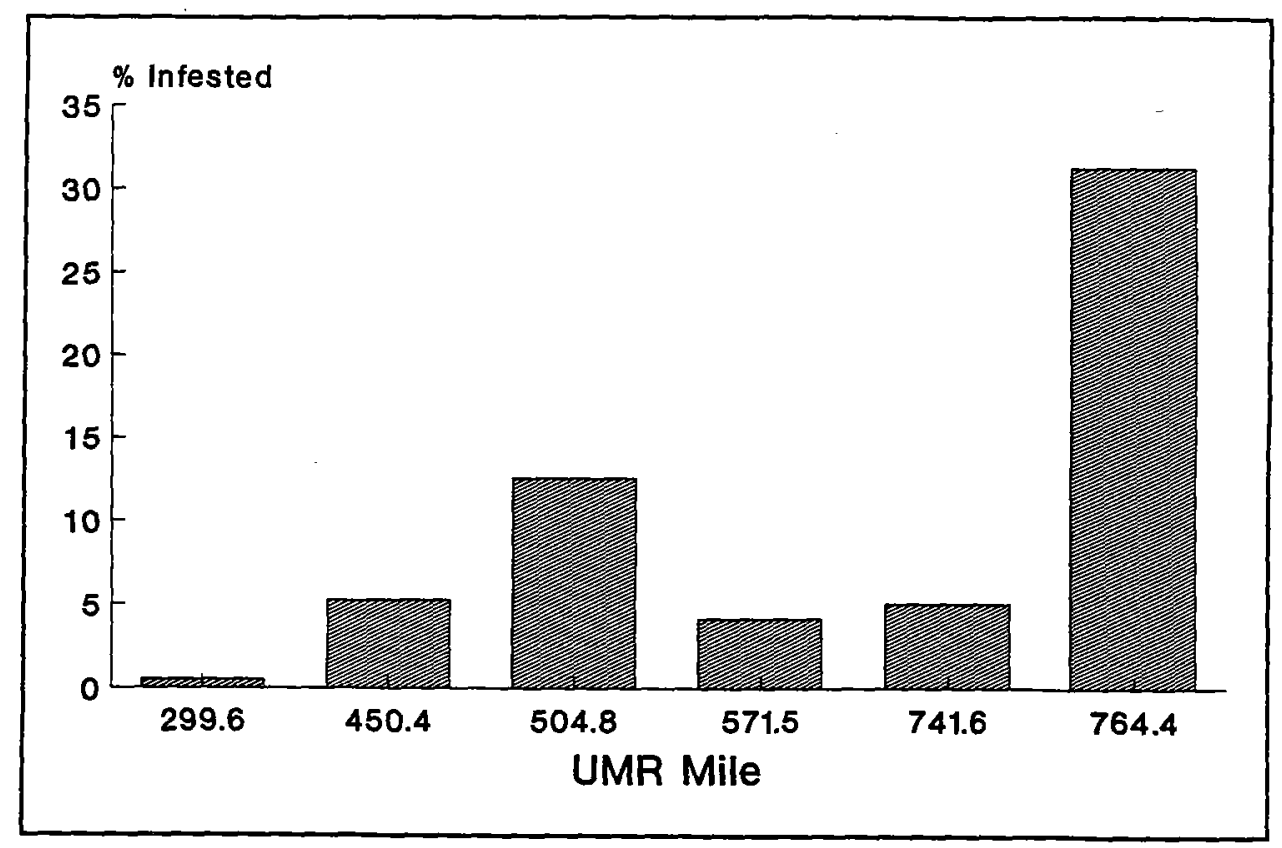

Figure 8. Percent unionids infested with zebra mussels at six locations in the UMR, including Pool 5 (RM 741.6) and immediately downriver of Lake Pepin (RM 764.4)

of the small sample of this site and confirmed recent recruitment of this species.

c. Dreissena polymorpha. Although very few individuals were collected, special interest in this introduced species justifies some inspection of size demography. At RM 741.6, eight individuals were obtained; the smallest was $13 \mathrm{~mm}$ long and the largest was $29 \mathrm{~mm}$ long. At

RM 764.4, 14 individuals were collected, and length ranged from 2 to $30 \mathrm{~mm}$. This wide size range suggests that at least two year classes were present at RM 764.4.

d. Size Demography of Dreissena polymorpha on Native Mussels in Pool 5 and Immediately Downriver of Lake Pepin. Size demography of zebra mussels attached to native mussels in Pool 5 and Lake Pepin was determined (Figure 12). Although sample sizes in both cases are small, data from both locations indicates that at least two year classes were probably present. In Pool 5, one cohort was less than $12 \mathrm{~mm}$ and the second cohort had a shell length between 18 and $32 \mathrm{~mm}$. Immediately downriver of Lake Pepin a single cohort was less than $10 \mathrm{~mm}$, and the second (and possibly third cohort) was greater than $12 \mathrm{~mm}$. Comparatively low-density populations, with simple size demography, are characteristic of nonindigenous species during early introduction. 


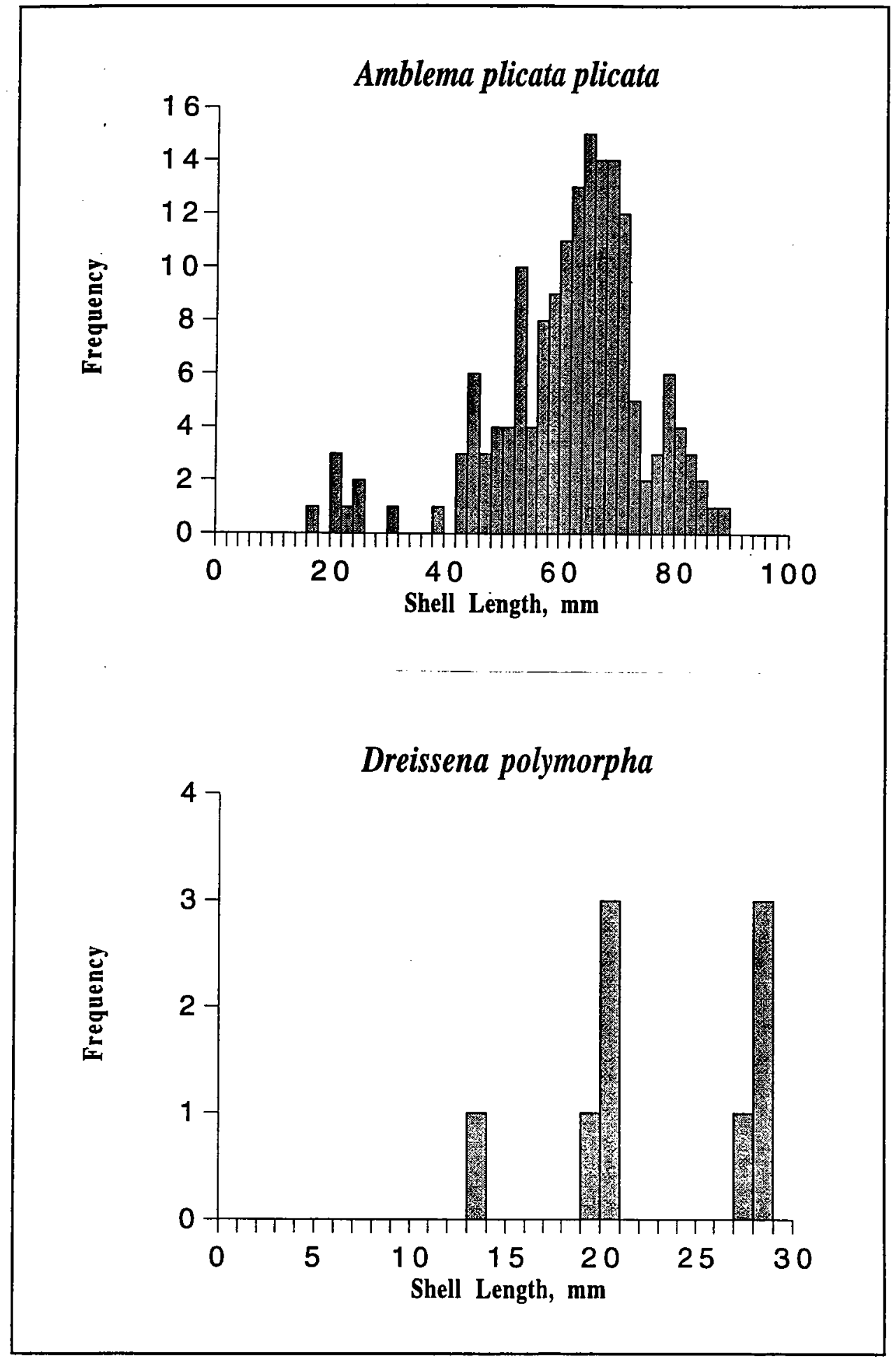

Figure 9. Size demography of dominant bivalves in Pool 5, 1994 

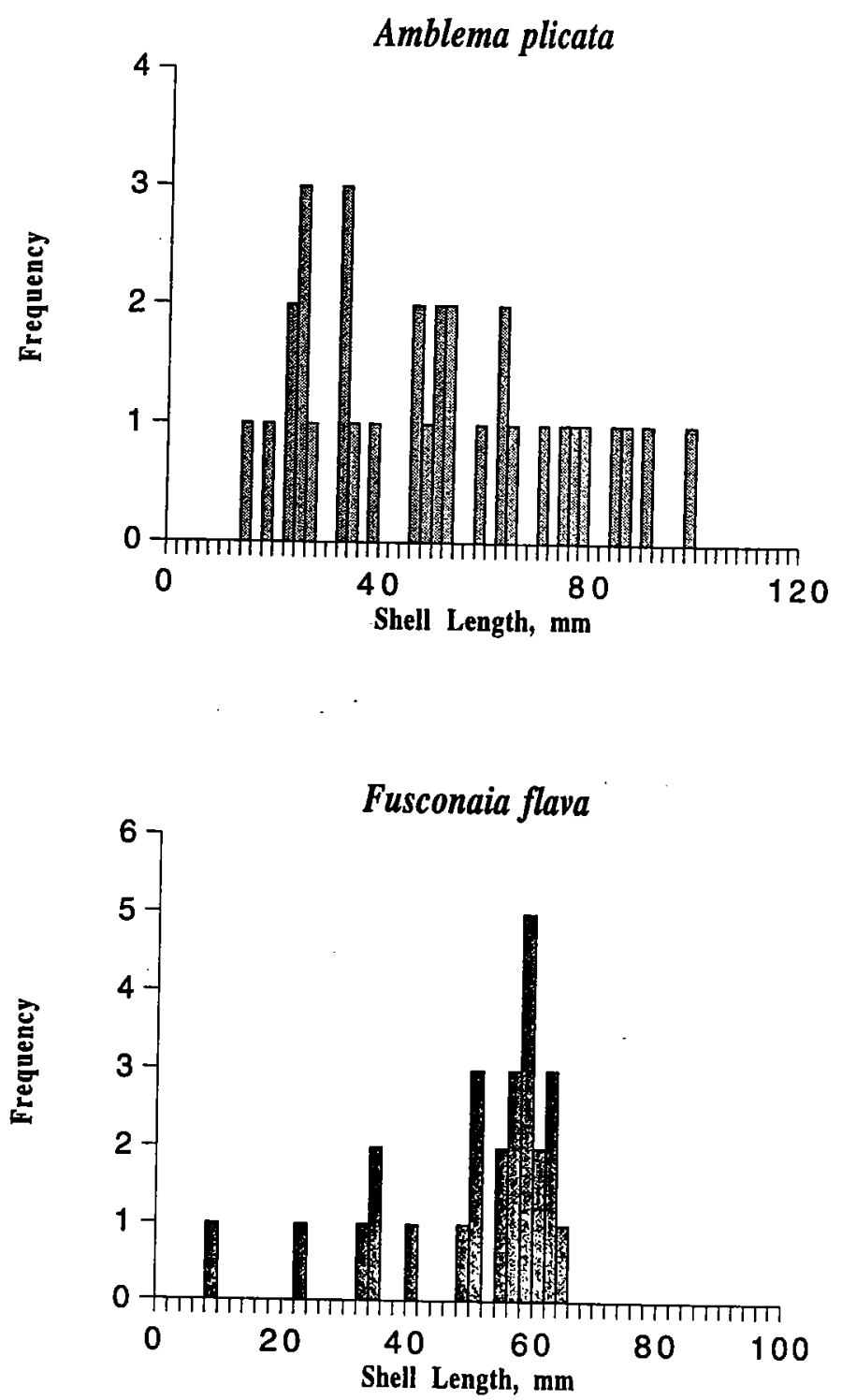

Figure 10. Size demography of dominant bivalves in Lake Pepin, RM 776.3, 

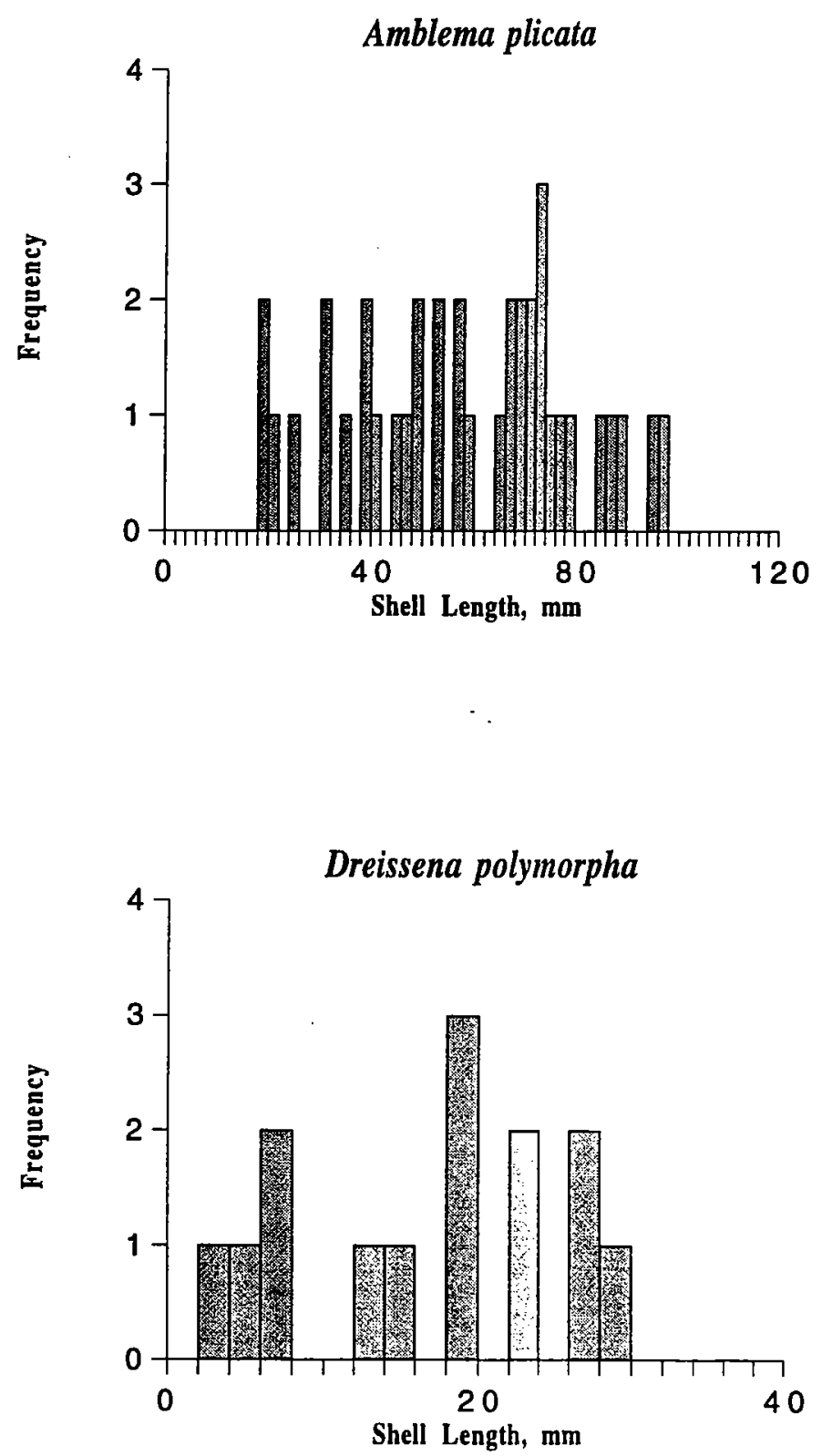

Figure 11. Size demography of dominant bivalves immediately downriver of Lake Pepin, RM 764.4, 1994 


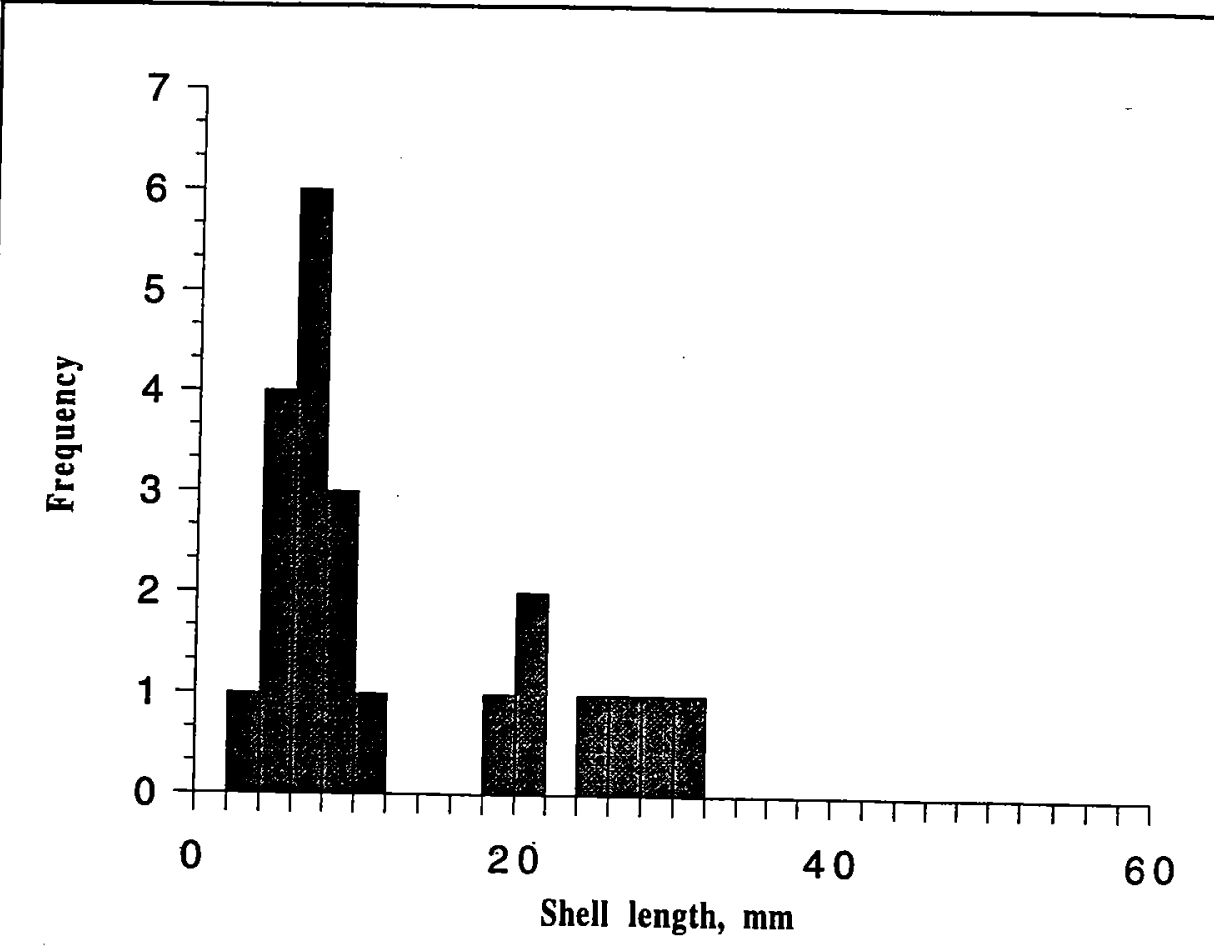

a. Pool 5

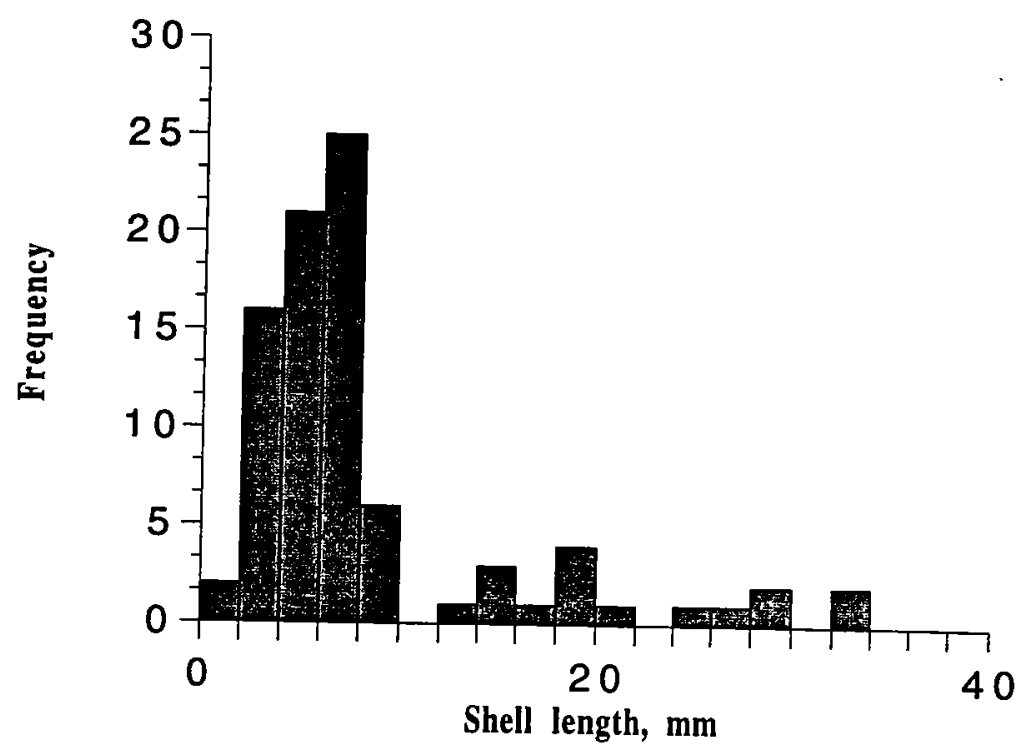

b. Downriver of Lake Pepin

Figure 12. Size demography of Dreissena polymorpha on native mussels 


\section{Discussion}

\section{Community and Population Characteristics}

Based upon quantitative sampling, total species richness of native species at study sites in Pool 5 (12) and Lake Pepin (12) was slightly less than that at other mussel beds in large rivers. For example, at a bed in the lower Ohio River near Olmsted, IL, 23 species of freshwater mussels were identified. In a survey of the lower Tennessee River, Miller, Payne, and Tippit (1992) collected 4,768 individuals and identified 23 species. In the East Channel of the UMR, there are approximately 30 species of mussels (Miller and Payne 1993a).

It is likely that additional species would be identified if more samples had been taken providing the opportunity of finding less common species. However, unionid species richness declines moving north along the UMR. Areas north of St. Paul, MN, located approximately at RM 836, are outside the range of Quadrula nodulata, Quadrula quadrula, Quadrula p. pustulosa, A. p. plicata, Megalonaias nervosa and many other unionids common in the lower pools of the UMR (Cummings and Mayer 1992).

Typically, the unionid fauna of most large-river mussel beds is dominated by 1 to 3 species. Based upon quantitative collections made at various location in the UMR in 1994, dominance of $A$. $p$. plicata ranged from 23.3 percent at a bed in Pool 24 to 48.97 percent at RM 635.2 in the main channel of the UMR, Pool 10. The tendency of this species to dominate in the upper part of the UMR was maintained at sites in Lake Pepin and Pool 5. This species is not always dominant at mussel beds in large rivers; at a bed in the middle Ohio River near Cincinnati, $\mathrm{OH}$, the fauna was dominated by Pleurobema cordatum and $Q$. p. pustulosa which together comprised 39.9 percent of the assemblage (Miller and Payne 1993b). At that location, A. p. plicata comprised approximately 10 percent of the fauna. In a 1992 survey at a dense and diverse bed in the lower Ohio River, Fusconaia ebena comprised 21 and 47 percent of the unionid assemblage immediately up and downriver of Lock and Dam 53. Amblema p. plicata comprised only 2 and 3 percent of the assemblage at these two locations (Payne and Miller in preparation). 
Extreme dominance by a single species reduces species diversity values $\left(\mathrm{H}^{\prime}\right)$. For example, at $\mathrm{RM} 764.4$ (immediately downriver of Lake Pepin), A. $p$. plicata comprised 37.8 percent of the fauna, and the $\mathrm{H}^{\prime}$ was 1.8 . In Pool 5, A. p. plicata comprised approximately 60 percent of the fauna and $\mathrm{H}^{\prime}$ was less than 1.50 .

In comparison with other large-river mussel beds, the range in density immediately downriver of Lake Pepin (19.6 individuals $/ \mathrm{m}^{2}$ ) can be considered low to moderate. At an inshore and offshore site in the lower Tennessee River sampled in 1986, (32 quantitative samples were collected at each site) total mussel density was 187.7 and 79.7 individuals $/ \mathrm{m}^{2}$, respectively (Way, Miller, and Payne 1989). Downriver of Lock No 53 in the lower Ohio River, total unionid density was 82 to 105 individuals $/ \mathrm{m}^{2}$ at mid- to farshore sites (Payne and Miller 1995). In the middle Ohio River near Cincinnati, mussel density ranged from 4.4 to 52.4 individuals $/ \mathrm{m}^{2}$ (Miller and Payne 1993b). In a survey of the upper Mississippi River, Miller et al. (1990) reported that total mussel density ranged from 5.2 to 333.2 individuals $/ \mathrm{m}^{2}$ at 16 sites (10 quantitative samples were taken at each). At one-half of the sites, total density was greater than 50 individuals $/ \mathrm{m}^{2}$, and at four sites, it was greater than 100 individuals $/ \mathrm{m}^{2}$.

The number of individuals less than 30-mm total shell length provides an estimate of recent recruitment. Individuals of this size are less than 3 years old and their presence indicates that conditions were appropriate for successful recent reproduction. The overall percentage of indigenous recent recruits of species (excluding $C$. fluminea and $D$. polymorpha) was 10 to 20 percent at most sites. It would appear that Unionidae at all sites, regardless of water depth, proximity to wingdams, or location are similar with respect to recent recruitment.

Occasionally, mussel beds are studied that exhibit evidence of very strong recent recruitment. At a mussel bed in the lower Ohio River, a single cohort of $F$. ebena with an average shell length of $15.8 \mathrm{~mm}$ represented 71 percent of the population (Payne and Miller 1989).

\section{Consideration of Dreissena polymorpha}

The first report of $D$. polymorpha in North America was from Lake St. Clair in June 1988 (Hebert, Muncaster, and Mackie 1989). By late summer 1989, zebra mussels had spread downstream into the Detroit River, Lake Erie, Niagara River, and western Lake Ontario (Griffiths, Kovalak, and Schloesser 1989). By late September 1990, zebra mussels had spread through Lake Ontario and down the St. Lawrence River to Massena, NY. In June 1991, biologists from the Illinois Natural History Survey found adult zebra mussels at Illinois River Miles 50, 60, and 110 (Sparks and Marsden 1991). This species was first collected at a mussel bed in the lower Ohio River near Lock and Dam 53 in the fall of 1991 (Payne and Miller in preparation). 
By early January 1993, zebra mussels had spread throughout most of the inland waterway system. They probably reached sites on hulls of commercial navigation vessels (Keevin, Yarbrough, and Miller 1992). By this time they were in the lower Mississippi River as far south as Vicksburg, MS, and in the upper Mississippi River near St. Paul, MN (Dreissena polymorpha Information Review 1992). This species will probably continue to spread throughout North America where suitable habitat exists (Strayer 1990).

Approximately 30 percent of the native mussels collected immediately downriver of Lake Pepin were infested with 1 to 5 zebra mussels. An infestation of approximately 200 zebra mussels per unionid was reported by Lewandowski (1976) to negatively affect unionids in Europe. In 1993, densities at sites in the lower Illinois River reached nearly $100,000 / \mathrm{m}_{2}$, although numbers declined rapidly within 1 year (Whitney, Blodgett, and Sparks 1995). Unionid infestation rates ranged from 80 to nearly 100 percent in 1993. Based upon information from other parts of the inland waterway system, it is likely that much higher numbers of zebra mussels will be found in the Lake Pepin, Pool 5, and other parts of the UMR in 1995 or 1996. A nonindigenous species usually achieves high densities after initial introduction, then numbers decline rapidly as resources diminish and parasites and predators become more abundant. Unlike the case of $C$. fluminea-unionid interactions, which are not always adverse (Miller and Payne 1994), zebra mussels are likely to have negative localized effects on native mussels.

\section{Value of Wingdams for Freshwater Mussels}

Results of sampling on and between wingdams demonstrate the value of this type of habitat for freshwater mussels. Although the large rock and cobble do not allow these organisms to bury as they do in sand and gravel, the protection and stability provided by wingdams is important. Although these areas are difficult to sample, wingdams at various locations in the UMR all support dense and diverse assemblages of mussels, and when in its range, the endangered L. higginsi (Miller et al. 1990; Miller and Payne in preparation). 


\section{Concluding Comments}

Mussels were collected at sites in Pool 5, near Winona, MN, and in Pool 4 near Lake City, MN, in 1994. In Pool 5, mussels were collected on and between two wingdams. In Pool 4, mussels were collected in Lake Pepin as well as immediately downriver of the lake. In comparison to other sites in large waterways, densities and species richness at these sites were low to moderate. However, these locations are near the northern portion of the geographic range of many unionids. Evidence of recent recruitment was considered good; typically, 20 to 40 percent of the individuals and species were located near less than $30-\mathrm{mm}$ total shell length and were probably 1 to 2 years old.

Approximately 31 percent of the native unionids collected immediately downriver of Lake Pepin had one or more attached zebra mussels. Compared to other beds sampled in the UMR in 1994, these numbers were high. Densities on the substratum were low, usually less than five individuals $/ \mathrm{m}^{2}$ at sites in Pool 5 or immediately downriver of Lake Pepin. However, it is likely that total numbers of zebra mussels will increase at these sites in the next few years.

Data on density, species diversity, evidence of recent recruitment, and other biotic parameters at these locations in the UMR will serve as a baseline to compare results of future studies. These quantitative and qualitative data can be used to evaluate effects of movement of commercial navigation traffic, maintenance dredging, periods of extreme low and high water, or the effects of introduction and spread of exotic species such as $D$. polymorpha. 


\section{References}

Burch, J. B. (1975). Freshwater unionacean clams (Mollusca: Pelecypoda) of North America. Malacological Publications, Hamburg, MI.

Cummings, K. S., and Mayer, C. A. (1992). "Field guide to freshwater mussels of the Midwest." Illinois Natural History Survey. Champaign, IL.

Dreissena polymorpha Information Review. (1992). Published by Zebra Mussel Information Clearing House of New York Sea Grant, Brochport, NY.

Griffiths, R. W., Kovalak, W. P., and Schloesser, D. W. (1989). “The zebra mussel, Dreissena polymorpha (Pallas 1771), in North America: Impacts on raw water users." Symposium: Service Water System Problems Affecting Safety-Related Equipment. Charlotte, NC, Nuclear Power Division, Electric Power Research Institute, Palo Alto, CA, 11-26.

Hebert, P. D. N., Muncaster, B. W., and Mackie, G. L. (1989). "Ecological and genetic studies on Dreissena polymorpha (Pallas): A new mollusc in the Great Lakes." Canadian Journal of Fisheries and Aquatic Sciences 46, 1587-1591.

Isom, B. G., and Gooch, C. (1986). "Rationale and sampling design for fresh-water mussels, unionidae, in streams, large rivers, impoundments, and lakes," Rationale for Sampling and Interpretation of Ecological Data in the Assessment of Freshwater Ecosystems, ASTM STP 894, B. G. Isom, ed., American Society for Testing and Materials, Philadelphia, PA.

Keevin, T. M., Yarbrough, R. E., and Miller, A. C. (1992). “Longdistance dispersal of zebra mussels (Dreissena polymorpha) attached to hulls of commercial vessels," Journal of Freshwater Ecology 7(4), 437. 
Kovalak, W. P., Dennis, S. D., and Bates, J. M. (1986). "Sampling effort required to find rare species of freshwater mussels," Rationale for Sampling and Interpretation of Ecological Data in the Assessment of Freshwater Ecosystems, ASTM STP 894, B. G. Isom, ed., American Society for Testing and Materials, Philadelphia, PA.

Lewandowski, K. (1976). "Unionidae as a substratum for Dreissena polymorpha Pall," Polskie Archiwum Hydrobiologii 23, 409-420.

Miller, A. C., and Payne, B. S. (1988). "The need for quantitative sampling to characterize size demography and density of freshwater mussel communities," Bulletin of the American Malacological Union, Inc. 6, 49-54.

Miller, A. C., Payne, B. S., Hornbach, D. J., and Ragland, D. V. (1990). "An investigation of the physical effects of increased commercial navigation traffic on freshwater mussels in the Upper Mississippi River: Phase I studies," Technical Report EL-90-3, U.S. Army Engineer Waterways Experiment Station, Vicksburg, MS.

Miller, A. C., Payne, B. S., and Tippit, R. (1992). "Characterization of a freshwater mussel (Unionidae) community immediately downriver of Kentucky Lock and Dam in the Tennessee River." Transactions of the Kentucky Academy of Sciences 53(3-4), 154-161.

Miller, A. C., and Payne, B. S. (1993a). "The effects of commercial navigation traffic on freshwater mussels in the Upper Mississippi River: 1991 studies," Technical Report EL-93-1, U.S. Army Engineer Waterways Experiment Station, Vicksburg, MS.

(1993b). "Qualitative versus quantitative sampling to evaluate population and community characteristics at a large-river mussel bed," The American Midland Naturalist 130, 133-145.

Miller, A. C., Payne, B. S., Shafer, D. J., and Neill, L. T. (1994). "Techniques for monitoring freshwater bivalve communities and populations in large rivers," Proceedings of The Conservation and Management of Freshwater Mussels, October 12-14, 1992. St. Louis, MO, 147-158.

Miller, A. C., and Payne, B. S. (1994). "Co-occurrence of native freshwater mussels (Unionidae) and the nonindigenous Corbicula fluminea at two stable shoals in the Ohio River," Malacological Review 27, 87-97.

. (1996). "The importance of a mussel bed near McMillan Island, Pool 10 of the upper Mississippi River, for Lampsilis higginsi," Technical Report in preparation, U.S. Army Engineer Waterways Experiment Station, Vicksburg, MS. 
Murray, H. D., and Leonard, A. B. (1962). Handbook of Unionid Mussels in Kansas. Museum of Natural History, University of Kansas, Lawrence, Kansas.

Parmalee, P. W. (1967). "The fresh-water mussels of Illinois," Illinois State Museum Popular Science Series 8, 1-108.

Payne, B. S., and Miller, A. C. (1987). "Effects of current velocity on the freshwater bivalve Fusconaia ebena," Bulletin of the American Malacological Union, Inc. 5, 177-179.

- (1989). "Growth and survival of recent recruits to a population of Fusconaia ebena (Bivalvia: Unionidae) in the lower Ohio River," American Midland Naturalist 121, 99-104.

Payne, B. S., and Miller, A. C. "Analysis of freshwater mussel (unionidae) populations in the lower Ohio River, 1993-94 studies," Technical Report in preparation, U.S. Army Engineer Waterways Experiment Station, Vicksburg, MS.

Shannon, C. E., and Weaver, W. (1949). The mathematical theory of communication. University of Illinois Press, Urbana, IL.

Sparks, R., and Marsden, E. (1991). “Zebra mussel alert,” Illinois Natural History Survey Reports 310, 1-2.

Starrett, W. C. (1971). "A survey of the mussels (Unionidae) of the Illinois River: A polluted stream," Illinois Natural History Survey Bulletin 30(5), 266-403.

Strayer, D. L. (1990). "Projected distribution of the zebra mussel, Dreissena polymorpha, in North America," Canadian Journal of Fisheries and aquatic Sciences 48, 1389-1395.

Way, C. M., Miller, A. C., and Payne, B. S. (1989). "The influence of physical factors on the distribution and abundance of freshwater mussels (Bivalvia: Unionidae) in the lower Tennessee River," The Nautilus 103, 96-98.

Whitney, S. D., Blodgett, K. D., and Sparks, R. E. (1995). "Update on zebra mussels and native unionids in the Illinois River," The UMRCC Newsletter, 13-14.

Williams, J. D., Warren, M. L., Jr., Cummings, K. S., Harris, J. L., and Neves, R. J. (1992). "Conservation status of freshwater mussels of the United States and Canada," Fisheries 18, 6-22. 


\section{Appendix A}

Freshwater Bivalves Collected

Using Quantitative Methods at

Two Locations in Pool 5, 1994

\begin{tabular}{|c|c|c|c|c|c|c|}
\hline \multicolumn{7}{|c|}{$\begin{array}{l}\text { Table A1 } \\
\text { Percent Abundance of Species and Occurre } \\
\text { Wingdam in Pool 5, RM 741.6, UMR, } 1995\end{array}$} \\
\hline \multirow[b]{2}{*}{ Species } & \multicolumn{2}{|c|}{ Subsite 1} & \multicolumn{2}{|c|}{ Subsite 2} & \multicolumn{2}{|c|}{ Total } \\
\hline & Abundance & Frequency & Abundance & Frequency & Abundance & Frequency \\
\hline A. p. plicata & 56.41 & 100.00 & 64.15 & 100.00 & 60.09 & 100.00 \\
\hline T. truncata & 15.38 & 80.00 & 1.89 & 20.00 & 8.97 & 50.00 \\
\hline F. flava & 3.42 & 40.00 & 12.26 & 80.00 & 7.62 & 60.00 \\
\hline O. reflexa & 4.27 & 40.00 & 5.66 & 40.00 & 4.93 & 40.00 \\
\hline L. fragilis & 5.98 & 50.00 & 1.89 & 10.00 & 4.04 & 30.00 \\
\hline D. polymorpha & 4.27 & 40.00 & 3.77 & 40.00 & 4.03 & 40.00 \\
\hline L. cardium & 2.56 & 20.00 & 4.72 & 40.00 & 3.59 & 30.00 \\
\hline Q. p. pustulosa & 1.71 & 20.00 & 4.72 & 30.00 & 3.14 & 25.00 \\
\hline L. recta & 3.42 & 40.00 & 0.00 & 0.00 & 1.79 & 20.00 \\
\hline P. rubrim & 1.71 & 20.00 & 0.00 & 0.00 & 0.90 & 10.00 \\
\hline L. siliquoidea & 0.00 & 0.00 & 0.94 & 10.00 & 0.45 . & 5.00 \\
\hline L. complanata & 0.85 & 10.00 & 0.00 & 0.00 & 0.45 & 5.00 \\
\hline Total individuals & 117 & & 106 & & 223 & \\
\hline Total species & 11 & & 9 & & 12 & \\
\hline Total samples & 10 & & 10 & & 20 & \\
\hline Percent individuals $<30 \mathrm{~mm}$ & 12.50 & & 3.92 & & 8.41 & \\
\hline Percent species $<30 \mathrm{~mm}$ & 30.00 & & 50.00 & & 36.36 & \\
\hline Menhinik's index & 0.95 & & 0.79 & & 0.75 & \\
\hline Diversity $\left(\mathrm{H}^{\prime}\right)$ & 1.44 & & 1.19 & & 1.41 & \\
\hline Evenness & 0.51 & & 0.50 & & 0.46 & \\
\hline
\end{tabular}




\begin{tabular}{|c|c|c|c|c|c|c|}
\hline \multicolumn{7}{|c|}{$\begin{array}{l}\text { Table A2 } \\
\text { Percent Abundance of Species and Occurrence of Freshwater Bivalves Between } \\
\text { Two Wingdam in Pool 5, RM 741.6, UMR, } 1995\end{array}$} \\
\hline \multirow[b]{2}{*}{ Species } & \multicolumn{2}{|c|}{ Subsite 1} & \multicolumn{2}{|c|}{ Subsite 2} & \multicolumn{2}{|c|}{ Total } \\
\hline & Abundance & Frequency & Abundance & Frequency & Abundance & Frequency \\
\hline A. p. plicata & 45.45 & 40.00 & 69.23 & 90.00 & 64.00 & 65.00 \\
\hline a. p. pustulosa & 36.36 & 30.00 & 5.13 & 20.00 & 12.00 & 25.00 \\
\hline F. flava & 9.09 & 10.00 & 5.13 & 20.00 & 6.00 & 15.00 \\
\hline o. reflexa & 9.09 & 10.00 & 5.13 & 20.00 & 6.00 & 15.00 \\
\hline P. rubrim & 0.00 & 0.00 & 5.13 & 20.00 & 4.00 & 10.00 \\
\hline T. truncata & 0.00 & 0.00 & 5.13 & 20.00 & 4.00 & 10.00 \\
\hline L. cardium & 0.00 & 0.00 & 2.56 & 10.00 & 2.00 & 5.00 \\
\hline Q. metanevra & 0.00 & 0.00 & 2.56 & 10.00 & 2.00 & 5.00 \\
\hline Total individuals & 11 & . & 39 & & 50 & \\
\hline Density & 15.60 & & 4.40 & & 10.00 & \\
\hline Standard error & 4.93 & & 1.39 & & 3.16 & \\
\hline Total species & 4 & & 8 & & 8 & \\
\hline Total samples & 10 & & 10 & & 20 & \\
\hline Percent individuals $<30 \mathrm{~mm}$ & 9.09 & & 12.82 & & 12.00 & \\
\hline Percent species < $30 \mathrm{~mm}$ & 25.00 & & 37.50 & & 50.00 & \\
\hline Menhinik's index & 1.21 & & 1.28 & & 1.13 & \\
\hline Diversity $\left(H^{\prime}\right)$ & 1.16 & & 1.20 & & 1.29 & \\
\hline Evenness & 1.11 & & 0.46 & & 0.51 & \\
\hline
\end{tabular}




\section{Appendix B}

Freshwater Bivalves Collected Using Quantitative Methods at Two Locations in Lake Pepin, 1994 
Table B1

Percent Abundance of Species Collected Using Quantitative Methods at 8 Sites in Lake Pepin, July 1994

\begin{tabular}{|c|c|c|c|c|c|c|c|c|c|}
\hline \multirow[b]{3}{*}{ Species } & \multicolumn{6}{|c|}{ River Mile 776.3} & \multirow{2}{*}{\multicolumn{2}{|c|}{$\begin{array}{l}\text { River Mile } 764.4 \\
\text { Depth: } 8-10 \mathrm{ft}\end{array}$}} & \multirow{3}{*}{$\begin{array}{l}\text { Grand } \\
\text { Total }\end{array}$} \\
\hline & \multicolumn{2}{|c|}{ Depth: $10 \mathrm{ft}$} & \multicolumn{4}{|c|}{ Depth: 5 ft } & & & \\
\hline & Site 3 & Site 4 & Site 5 & Site 6 & Site 7 & Site 8 & Site 9 & Site 10 & \\
\hline A. p. plicata & 50.00 & 75.00 & 47.37 & 23.53 & 53.85 & 28.57 & 40.35 & 34.15 & 39.88 \\
\hline F. flava & 25.00 & 0.00 & 42.11 & 58.82 & 30.77 & 21.43 & 1.75 & 0.00 & 15.61 \\
\hline D. polymorpha & 0.00 & 0.00 & 5.26 & 0.00 & 7.69 & 7.14 & 3.51 & 29.27 & 9.83 \\
\hline T. truncata & 0.00 & 0.00 & 0.00 & 11.76 & 0.00 & 0.00 & 17.54 & 4.88 & 8.09 \\
\hline L. cardium & 25.00 & 0.00 & 5.26 & 0.00 & 0.00 & 7.14 & 5.26 & 14.63 & 6.94 \\
\hline o. reflexa & 0.00 & 25.00 & 0.00 & 5.88 & 7.69 & 21.43 & 7.02 & 2.44 & 6.94 \\
\hline E. dilatata & 0.00 & 0.00 & 0.00 & 0.00 & 0.00 & 0.00 & 10.53 & 7.32 & 5.20 \\
\hline P. rubrim & 0.00 & 0.00 & 0.00 & 0.00 & 0.00 & 0.00 & 8.77 & 0.00 & 2.89 \\
\hline a. pustulosa & 0.00 & 0.00 & 0.00 & 0.00 & 0.00 & 0.00 & 1.75 & 4.88 & 1.73 \\
\hline L. recta & 0.00 & 0.00 & 0.00 & 0.00 & 0.00 & 0.00 & 3.51 & 0.00 & 1.16 \\
\hline a. metanevra & 0.00 & 0.00 & 0.00 & 0.00 & 0.00 & 0.00 & 0.00 & 2.44 & 0.58 \\
\hline T. donaciformis & 0.00 & 0.00 & 0.00 & 0.00 & 0.00 & 7.14 & 0.00 & 0.00 & 0.58 \\
\hline L. siliquoidea & 0.00 & 0.00 & 0.00 & 0.00 & 0.00 & 7.14 & 0.00 & 0.00 & 0.58 \\
\hline Total individuals & 4 & 8 & 19 & 17 & 13 & 14 & 57 & 41 & 173 \\
\hline Total species & 3 & 2 & 4 & 4 & 4 & 7 & 10 & 8 & 13 \\
\hline Percent individuals $<30 \mathrm{~mm}$ & 25 & 25 & 16.67 & 17.65 & 25 & 30.76 & 23.64 & 10.34 & 20.51 \\
\hline Percent species $<30 \mathrm{~mm}$ & 33.33 & 100 & 13.33 & 50 & 66.67 & 66.67 & 44.44 & 42.85 & 58.33 \\
\hline Menhinik's index & 1.50 & 0.71 & 0.71 & 0.97 & 0.87 & 1.67 & 1.21 & 1.30 & 0.96 \\
\hline Diversity $\left(\mathrm{H}^{\prime}\right)$ & 1.05 & 0.56 & 0.87 & 1.07 & 0.89 & 1.63 & 1.75 & 1.51 & 1.78 \\
\hline Evenness & 2.14 & 0.99 & 1.01 & 0.84 & 1.01 & 1.34 & 0.73 & 0.75 & 0.62 \\
\hline
\end{tabular}




\begin{tabular}{|c|c|c|c|c|c|c|c|c|c|}
\hline \multicolumn{10}{|c|}{$\begin{array}{l}\text { Table B2 } \\
\text { Percent Occurrence of Species Collected Using Quantitative Methods at } 8 \text { Sites in Lake Pepin, July } 1994\end{array}$} \\
\hline \multirow[b]{3}{*}{ Species } & \multicolumn{6}{|c|}{ River Mile 776.3} & \multirow{2}{*}{\multicolumn{2}{|c|}{$\begin{array}{l}\text { River Mile } 764.4 \\
\text { Depth: } 8-10 \mathrm{ft}\end{array}$}} & \multirow[b]{3}{*}{ Grand Total } \\
\hline & \multicolumn{2}{|c|}{ Depth: $10 \mathrm{ft}$} & \multicolumn{4}{|c|}{ Depth: $5 \mathrm{ft}$} & & & \\
\hline & Site 3 & Site 4 & Site 5 & Site 6 & Site 7 & Site 8 & Site 9 & Site 10 & \\
\hline A.p. plicata & 10.00 & 40.00 & 70.00 & 40.00 & 60.00 & 20.00 & 90.00 & 60.00 & 48.75 \\
\hline F. flava & 10.00 & 0.00 & 60.00 & 80.00 & 40.00 & 30.00 & 10.00 & 0.00 & 28.75 \\
\hline T. truncata & 0.00 & 0.00 & 0.00 & 20.00 & 0.00 & 0.00 & 90.00 & 20.00 & 16.25 \\
\hline O. reflexa & 0.00 & 20.00 & 0.00 & 10.00 & 10.00 & 30.00 & 30.00 & 10.00 & 13.75 \\
\hline D. polymorpha & 0.00 & 0.00 & 10.00 & 0.00 & 10.00 & 10.00 & 20.00 & 60.00 & 13.75 \\
\hline L. cardium & 10.00 & 0.00 & 10.00 & 0.00 & 0.00 & 10.00 & 20.00 & 50.00 & 12.50 \\
\hline E. dilatata & 0.00 & 0.00 & 0.00 & 0.00 & 0.00 & 0.00 & 40.00 & 30.00 & 8.75 \\
\hline P. rubrim & 0.00 & 0.00 & 0.00 & 0.00 & 0.00 & 0.00 & 50.00 & 0.00 & 6.25 \\
\hline a.p. pustulosa & 0.00 & 0.00 & 0.00 & 0.00 & 0.00 & 0.00 & 10.00 & 20.00 & 3.75 \\
\hline L. recta & 0.00 & 0.00 & 0.00 & 0.00 & 0.00 & 0.00 & 20.00 & 0.00 & 2.50 \\
\hline T. donaciformis & 0.00 & 0.00 & 0.00 & 0.00 & 0.00 & 10.00 & 0.00 & 0.00 & 1.25 \\
\hline L. siliquoidea & 0.00 & 0.00 & 0.00 & 0.00 & 0.00 & 10.00 & 0.00 & 0.00 & 1.25 \\
\hline Q. metanevra & 0.00 & 0.00 & 0.00 & 0.00 & 0.00 & 0.00 & 0.00 & 10.00 & 1.25 \\
\hline Total samples & 10 & 10 & 10 & 10 & 10 & 10 & 10 & 10 & 80 \\
\hline
\end{tabular}




\section{REPORT DOCUMENTATION PAGE}

Public reporting burden for this collection of information ts estimated to average 1 hour per response, incluoing the time for reviewing hstructions, searching extsting data sources, gathering and maintalning the data needed, and completting and reviowing the collection of information. Send comments regarding this burden estimate or any other aspect of this collection of information, inctuding suggestions for reducing this burden, to Washington Headquarters Services, Directorate for inlormation Operations and Reports, 1215 Jefferson Davis Highway, Sutte 1204, Avlington, VA22202-4302, and to the Office of Management and Budget, Papenwork Reduction Project (0704-0188), Wastington, DC20503.

\begin{tabular}{|c|c|c|}
\hline 1.AGENCY USE ONLY (Leave blank) & $\begin{array}{c}\text { 2.REPORT DATE } \\
\text { September 1996 }\end{array}$ & $\begin{array}{l}\text { 3.REPORT TYPE AND DATES COVERED } \\
\text { Final report }\end{array}$ \\
\hline
\end{tabular}

4.TITLE AND SUBTITLE

Analysis of Freshwater Mussels (Unionidae) at Specific Sites in Pool 5 and

Lake Pepin, Upper Mississippi River, 1994

5.FUNDING NUMBERS

\section{AUTHOR(S)}

Andrew C. Miller, Barry S. Payne

7.PERFORMING ORGANIZATION NAME(S) AND ADDRESS(ES)

U.S. Army Engineer Waterways Experiment Station

3909 Halls Ferry Road, Vicksburg, MS 39180-6199

8.PERFORMING ORGANIZATION REPORT NUMBER

Technical Report

EL-96-13

9.SPONSORINGMONITORING AGENCY NAME(S) AND ADDRESS(ES)

U.S. Army Engineer Division, North Central

10.SPONSORINGMONITORING AGENCY REPORT NUMBER

Chicago, IL 60606-7205

\section{SUPPLEMENTARY NOTES}

Available from National Technical Information Service, 5285 Port Royal Road, Springfield, VA 22161.

\section{DISTRIBUTIONYVAILABIUTY STATEMENT}

12b.DISTAIBUTION CODE

Approved for public release; distribution is unlimited.

\section{ABSTRACT (Maximum 200 words)}

In July 1994, freshwater mussels were collected using qualitative and quantitative (0.25 sq $\mathrm{m}$ total substratum) methods at the following locations in the upper Mississippi River (UMR): directly on and between two wingdams at river mile (RM) 741.6 in Pool 5, Lake Pepin (RM 776.8), and an area immediately downriver of Lake Pepin (RM 764.4). The purpose was to document density, species diversity, species richness, community composition of native mussels, and density and percent abundance of the recently introduced nonindigenous zebra mussel, Dreissena polymorpha.

Between wingdams in Pool 5, total density was 10.0 individuals $/ \mathrm{m}^{2}$ and a total of eight species were collected. The fauna was dominated by A. p. plicata and Quadrula p. pustulosa. Moderate-to-good evidence of recent recruitment was indicated by the fact that 12 percent of the individuals and 50 percent of the species were less than $30 \mathrm{~mm}$ in total shell length. Using a suction dredge, a total of 223 individuals and 12 species of native mussels were collected in 20 samples on a wingdam. The fauna was dominated by $A$. p. plicata, which comprised 60 percent of the fauna and was collected in 100 percent of the samples. There was evidence of recent recruitment: 8.4 percent of the individuals and 36.4 percent of the species were less than $30 \mathrm{~mm}$ in total shell length.

(Continued)

\section{SUBJECT TERMS}

Freshwater mussels

Unionidae

Upper Mississippi River
15.NUMBER OF PAGES

42

16.PRICE CODE

\begin{tabular}{|c|c|c|}
\hline $\begin{array}{c}\text { 17.SECURITY CLASSIFICATION } \\
\text { OF REPORT } \\
\text { UNCLASSIFIED }\end{array}$ & $\begin{array}{c}\text { 18.SECURITY CLASSIFICATION } \\
\text { OF THIS PAGE } \\
\text { UNCLASSIFIED }\end{array}$ & $\begin{array}{c}\text { 19.SECURITY CLASSIFICATION } \\
\text { OF ABSTRACT }\end{array}$ \\
\hline
\end{tabular}




\section{3. (Concluded).}

In Lake Pepin, total density of native mussels was 2.4 individuals $/ \mathrm{m}^{2}$ at a depth of $10 \mathrm{ft}$ and 6.3 individuals $/ \mathrm{m}^{2}$ at a depth of $5 \mathrm{ft}$. Evidence of recent recruitment was good at both water depths ( 22 to 25 percent of the individuals and 50 to 71 percent of the species were less than $30 \mathrm{~mm}$ in total shell length). Density in the reach immediately downriver of Lake Pepin was 19.6 individuals $/ \mathrm{m}^{2}$, which was significantly greater $(\mathrm{p}<0.05)$ than in the lake. At this location, 19 percent of the individuals and 50 percent of the species showed evidence of recent recruitment.

Percent abundance of $D$. polymorpha was greater immediately downriver of the lake (14.3 percent) than in the lake (4 percent), or at sites surveyed in Pool 5 (less than 5 percent). Total density of $D$. polymorpha in Lake Pepin at 5-ft depth was 0.3 , and immediately downriver of the lake total density was 2.8 individuals/m². Approximately 31 percent of the live unionids collected immediately downriver of Lake Pepin had at least one unionid attached to the shell. Zebra mussel infestation at this location was considerably greater than at mussel beds in Pools 24, 17, 14, 12, and 10, according to a 1994 survey. Although it is extremely likely that zebra mussel densities will increase dramatically in the UMR within the next few years, in 1994 this species had no measurable negative effects on native mussels. 